\title{
Airflow over the Kii Peninsula and its Relation to the Orographic Enhancement of Rainfall
}

\author{
by \\ Kazuo Saito \\ Meteorological Research Institute, Tsukuba, Ibaraki, 305 Japan \\ Lecong Thanh* and Takao Takeda \\ Institute for Hydrospheric and Atmospheric Sciences, Nagoya University \\ Chikusa-ku, Nagoya, 464-01 Japan
}

(Received July 28, 1994 ; Revised December 13, 1994)

\begin{abstract}
In order to study the orographic effect on the rainfall distribution in the Kii peninsula, airflow over a three-dimensional mountains is simulated by use of a non-hydrostatic model and compared with the observed distribution of rainfall.

Numerical experiments for simplified orography show that low-level updraft areas have two peaks in weak wind cases. The first peak is on the windward slope of the mountain, while the secondary peak is over the sea, which is associated with the low-level blocking by the mountain. Locations of both updraft areas shift upstream as wind velocity decreases, while in cases of stronger wind or less atmospheric stability, no secondary peak appears over the sea. The characteristic curvature of the orography of the Kii peninsula intensifies the low-level blocking in the case of southeasterly environmental wind.

Heavy rainfall events in the Kii peninsula in 1985 are analyzed and it is confirmed that 1) the rainfall amount in each event at Owase tends to be higher than that at Shionomisaki, and 2) heavy rains occur at Owase when low-level synoptic wind is east-southeasterly to southerly. In numerical experiments for real orography of the Kii peninsula, low-level updrafts are found around Owase and the southern part of the Kii peninsula in easterly to southerly winds. The positions are well coincident with the positions of two maxima in mean annual rainfall distribution shown by Sakakibara and Takeda (1973). No secondary updraft occurs in the case of southwesterly to westerly winds.

Numerical simulations using atmospheric conditions observed in heavy rain events in 1985 are conducted. The locations of simulated low-level updrafts correspond well with the observed heavy rain areas around Owase and the southern part of the Kii peninsula. In some cases, middle-level updraft areas associated with mountain waves are computed aloft above the observed heavy rain areas to the northeast of Owase.

The experimental results are consistent with the empirical relation between the location of heavy-rain areas and wind speed: the sea-shore region in weak-wind type and the region deeper inland in strong-wind type. It is also suggested that low-level convergence due to the blocking effect of the mountains affects the orographic enhancement of the convective rain band which is often seen over the sea in the windward side of the Kii peninsula.
\end{abstract}

*) Present Affiliation: Forecast Department, Hydro-Meteorological Agency of Vietnum, 4-Dang thai Than, Hanoi, Vietnam

(C)1994 by the Meteorological Research Institute 


\section{Introduction}

It is well known that the distribution of precipitation is heavily dependent upon topography and that the rainfall amount has a tendency to be enhanced in the mountain regions. In Japan, the orographic enhancement of rainfall and the formation of heavy rain associated with orographic effect are often observed in the Kii peninsula. Especially Owase, a city located at the southeastern part of the Kii peninsula, is famous for its abundant rainfall which reaches 3000-4000 $\mathrm{mm}$ a year.

In the case study of rainfall during the passage of Typhoon 7002 over the Kii peninsula, Sakakibara and Takeda (1973) stated that the distribution of total rainfall during the typhoon passage resembles qualitatively to the mean annual rainfall distribution, which seems to have a good correlation with topographic features. In their study, rainfall at each station was interpreted in association with the amplification factor of rainfall which would be dependent upon topographic features and prevailing wind.

As pointed out by Takeda et al. (1976), heavy rain is often observed around Owase when the easterly to southeasterly wind is prevalent at low levels. In their case study, low-level radar echoes were observed persistently over the Owase area and heavy rains were recorded when traveling convective clouds entered these radar echoes. The supply of cloud water and rain water from orographic clouds into traveling convective clouds were considered to be important in the orographic enhancement of rainfall.

In a further study by Takeda and Takase (1980) on rainfall in the area around Owase, two types of rainfall were observed. The first type was convective rain concentrating into the limited area along the sea shore. The other type was continuous rain originated from middlelevel clouds which covered the broad area over the Kii peninsula. When the easterly wind was prevalent at low levels, a band-like cloud system was observed over the sea on the windward side of the mountain. A long-lasting cloud system was formed only around Owase after the bandlike cloud system dissipated.

A convergence zone of airflow caused by mountains was found in numerical experiments on Hawaiian cloud bands (Smolarkiewicz et al., 1988). They stated that cloud bands arose primarily from the dynamic modification of trade wind by the island. Their numerically simulated wind field revealed that upwind surface airflow formed a separation line with an associated stagnation point, and a low-level convergence zone was found along this line. Four factors were stated as conditions related to the formation of a cloud band: height and shape of a mountain, wind speed and direction, environmental stability and lifting condensation level.

Kikuchi et al. (1988) presented a study on orographic rainfall in the Orofure mountain region (Hokkaido, Japan). The horizontal distributions of rainfall in this region were classified into five patterns according to the location of heavy-rain area. The results of their numerical experiment show that the rainfall amount observed at the surface depends on wind velocity, topographic features and rainfall amount originated from middle-level clouds.

Smith $(1980 ; 1989 a)$ studied the linear theory of airflow around mountain and mentioned that airflow around a three-dimensional mountain exhibits many interesting phenomena in spite of the small number of control parameters. One of them is the splitting of airflow associated with a stagnation point. In the case of a sufficiently high mountain, central streamlines are unable to go over the top of the mountain and a stagnation point appears on the windward slope of the mountain. As a result of this, the central stream lines are split and pass around the mountain on both sides. Although Smith's study presented the theoretical behavior of the three-dimensional flow around a mountain, there are difficulties in applying his result directly to real flow for the purpose of understanding the orographic enhancement of rainfall. The linear-theory basically chooses the mountain wave with an infinitesimal height as the object of study. As will be shown later, the horizontal shift of location of the low-level updraft in the windward side of the mountain reflecting the variation of wind speed is not predicted in the linear theory.

Smolarkiewicz and Rotunno (1989 and 1990) 
studied non-linear flow around an isolated mountain by using a three-dimensional nonhydrostatic numerical model. When the nondimensional mountain height is near or greater than unity, their computational results showed the appearance of a pair of vertically oriented vortices on the lee side and the reversal flow zone on the windward side of the mountain. They presented the non-linear behavior of mountain flow that the linear theory cannot explain, but their numerical experiments were conducted using a simplified mountain shape with an idealized situation. Neither the surface friction nor internal diffusion were included in their experiments.

Mountain waves at middle levels have some effects on clouds and consequently on the horizontal distribution of rainfall around a mountain. Durran and Klemp (1982) made two-dimensional numerical experiments and suggested that lee waves can sometimes trigger the formation of convective storm if the upper layer is conditionally unstable and moist. Tripoli and Cotton (1989) demonstrated how convection initiated on the windward slope can be enhanced on the lee side of the Rocky mountains. Middle-level updraft associated with vertically propagating mountain wave was pointed out as an enhancing factor in the development of deep convection on the lee side of mountains.

The formation of orographic clouds is heavily dependent upon the flow around mountains, which would be very sensitive not only to atmospheric conditions, but to the shape of topography. Although a deeper understanding about airflow over a mountain is necessary, no three-dimensional numerical experiment using a non-hydrostatic model has ever been made in Japan to investigate orographic enhancement of rainfall. The relation between the flow around three-dimensional orography and the distribution of orographic rainfall has not been fully investigated.

In this study, we conduct numerical experiments using a three-dimensional nonhydrostatic model to study the orographic enhancement of rainfall in the Kii peninsula. Althoùgh the release of latent heat due to condensation of water vapor is important even in orographic rainfall, we switch off the cloud microphysics of the model in order to investigate the primary orographic forcing on the atmosphere by the Kii peninsula. We analyze numerically simulated orographic wind, focusing on its sensitivity to atmospheric conditions and topographic features, and compare it with the horizontal distribution of rainfall in the Kii peninsula.

In Section 2, the numerical model and design of experiments are described. In Section 3, the mountain flow over a mountain of an idealized shape is examined by numerical experiments. Sensitivity experiments to wind velocity, thermal stability and mountain shape are performed. In Section 4 , we study mountain flow over the real topography of the Kii peninsula. A brief analysis of rainfall in the Kii peninsula in 1985 is presented, and numerical experiments are conducted using four atmospheric conditions observed in heavy rainfall cases in 1985 . Section 5 describes the discussion. Summary is given in Section 6.

\section{Numerical model}

The numerical model used in this study is a three-dimensional, anelastic version of the non-hydrostatic model developed at the Forecast Research Department of the Meteorological Research Institute. The detailed description of the model is presented by Ikawa and Saito (1991).

The dynamical framework of the model is the anelastic system with terrain-following coordinate, which is similar to Clark (1977). Coriolis force is excluded in the experiments. To determine the diffusion coefficients, the turbulent closure model is employed. The formulation is based on Klemp and Wilhelmson (1978) and Deardorff (1980), and is identical to that described in Saito and Ikawa (1991a) and Saito (1993).

The upper boundary is a free-slip wall, while an absorbing layer with Rayleigh friction is imposed at the highest eight levels to prevent a false reflection of internal gravity waves. Lateral boundary condition is open, which incorporates Orlanski's (1976) radiation condition.

For the boundary layer physical processes, 
a resistance law calculates surface momentum fluxes. Over the land, the exchange coefficients are determined from Monin and Obukhov's similarity law for a given surface roughness length $(10 \mathrm{~cm})$ from the formula by Sommeria (1976). Over the sea, the exchange coefficients are determined from the formula by Kondo (1975). In the simulation, real land-sea distribution is used, while only momentum flux is calculated assuming the neutral stratification in the lowest surface boundary layer. The model incorporates cloud microphysics (Ikawa et al., 1991), but the numerical experiments in this study are conducted with a dry model.

The computational domain covers $400 \mathrm{~km} \times$ $400 \mathrm{~km}$, which contains $52 \times 52$ grid points horizontally. Grid intervals are $\Delta x=8 \mathrm{~km}$ and $\Delta y=$ $8 \mathrm{~km}$. Vertically, the model contains 32 levels, whose upper boundary is located at $\mathrm{H}=18 \mathrm{~km}$. Variable-grids are used with $\Delta z=40 \mathrm{~m}$ at the lowest level and $\Delta z=1200 \mathrm{~m}$ at the top of the domain. The lowest level of the horizontal winds is located at $20 \mathrm{~m}$ above ground surface. The time step is $\Delta t=30 \mathrm{~s}$. Computations are initiated in the horizontally homogeneous atmosphere, and we present results at 480 time step (4-hours model time) when the airflow pattern exhibited a nearly steady state.

\section{Flow over an idealized mountain}

Figure 1 shows the real topography in the Kii peninsula. As shown in this figure, the mountains in the Kii peninsula have a complicated shape. In this Section, first we examine the airflow around an idealized mountain in the situation of simplified atmospheric conditions.

The ellipsoid-shaped mountain whose height is given by

$z=\frac{h_{m}}{\left(\frac{x_{r}^{2}}{a^{2}}+\frac{y_{r}^{2}}{b^{2}}+1\right)^{\frac{3}{2}}}$,

is chosen as the idealized mountain (Fig. 2a). Here, $a=72 \mathrm{~km}$ and $b=28 \mathrm{~km}$, and $h_{m}$ is 1300 m. $x_{r}$ and $y_{r}$ is the distance from the mountaintop along the transformed rectangular axes given by

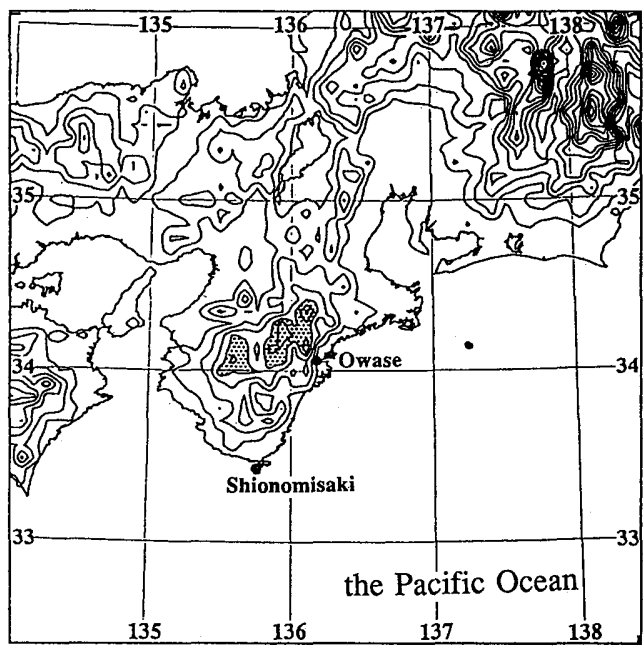

Fig. 1 Topography of the Kii peninsula. Contour interval is $200 \mathrm{~m}$.

$x_{r}=\left(x-x_{0}\right) \cos \frac{\pi}{4}+\left(y-y_{0}\right) \sin \frac{\pi}{4}$,

$y_{r}=-\left(x-x_{0}\right) \sin \frac{\pi}{4}+\left(y-y_{0}\right) \cos \frac{\pi}{4}$,

where $\left(x_{0}, y_{0}\right)$ is the position of the mountaintop.

The curved ellipsoid-shaped mountain whose radius of curvature is $92 \mathrm{~km}$ (Fig. $2 \mathrm{~b}$ ) is additionally used in sub-section 3.2. The experimental specifications and results in this Section are summarized in Table 1.

\subsection{Sensitivity of mountain flow to wind velocity}

All the numerical experiments presented in this sub-section are initiated with a constant lapse rate of potential temperature of $\mathrm{d} \theta / \mathrm{d} z=$ $3 \mathrm{~K} / \mathrm{km}$ and non-shear vertical wind profile. The stability of atmosphere, Brunt-Väisälä frequency, which is defined by

$$
N=\sqrt{\frac{g}{\theta} \frac{d \theta}{d z}}
$$

is about $0.01 / \mathrm{s}$ in this case. Wind direction is southeasterly, while environmental wind speed $U$ is variable from $5 \mathrm{~m} / \mathrm{s}$ to $20 \mathrm{~m} / \mathrm{s}$. The experiments are named EL05M, EL10M, EL15M and EL20M, according to the wind speed (Table $1)$.

Figure 3 shows the results of EL05M experiment, which was initiated with southeasterly wind of $5 \mathrm{~m} / \mathrm{s}$. The non-dimensional 

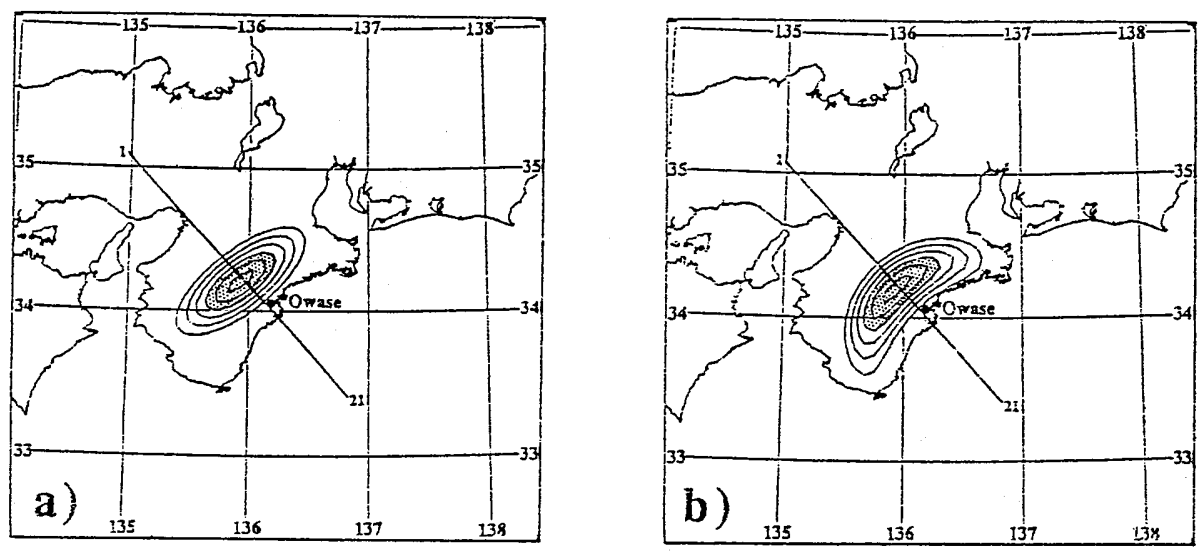

Fig. 2 (a) Ellipsoid-shaped mountain. Line 1-21 indicates the position of the vertical sections presented in sub-sections below. (b) Same as a) but for curved ellipsoid-shaped mountain.

Table 1 Results of experiments in Section 3

\begin{tabular}{|c|c|c|c|c|c|c|c|c|c|c|c|c|}
\hline & \multicolumn{4}{|c|}{ specification } & \multicolumn{5}{|c|}{ simulated results } & \multicolumn{3}{|c|}{ linear solution } \\
\hline $\begin{array}{l}\text { name of } \\
\text { xperiments }\end{array}$ & $\begin{array}{l}\mathrm{U} \\
(\mathrm{m} / \mathrm{s})\end{array}$ & $\begin{array}{l}\mathrm{d} \theta / \mathrm{dz} \\
(\mathrm{K} / \mathrm{km})\end{array}$ & $\begin{array}{c}\mathrm{N} \\
\left(\mathrm{s}^{-1}\right)\end{array}$ & $1 \mathrm{hm}$ & $\begin{array}{c}\lambda z \\
(\mathrm{~km})\end{array}$ & $\begin{array}{c}\mathrm{w}_{M 1} \\
(\mathrm{~cm} / \mathrm{s})\end{array}$ & $\begin{array}{l}\begin{array}{l}W_{1} \\
(k m) \\
(k m)\end{array} \\
\end{array}$ & $\begin{array}{r}w_{M 2} \\
(\mathrm{~cm} / \mathrm{s})\end{array}$ & $(\mathrm{km})$ & $\begin{array}{c}\lambda z \\
(\mathrm{~km})\end{array}$ & $\begin{array}{c}\mathrm{W} / \mathrm{M} \\
(\mathrm{cm} / \mathrm{s})\end{array}$ & $\begin{array}{l}w_{p}^{p} \\
k \mathrm{~km}\end{array}$ \\
\hline $5 \mathrm{M}$ & 5 & & & 2.6 & 3.2 & 1.6 & 29 & 2.4 & 50 & 3.1 & 3.3 & \\
\hline & 10 & 3 & $1.0 \times 10^{-2}$ & e & 5.9 & 7.6 & 29 & 8 & 4 & 6.3 & 0 & \\
\hline & 15 & & & 0 . & 8.8 & 13 & 22 & 15 & 40 & 9. & & \\
\hline & 20 & & & 0. & 13.0 & 48 & 22 & --- & - & 12. & 57 & \\
\hline 01 & 10 & & $1.4 \times 10$ & 1.8 & 4.2 & 1.6 & 34 & 5 & 62 & 5 & 1 & 3 \\
\hline 0 & 10 & 0. & $0 x$ & 0.34 & - & 28 & 22 & $-\infty$ & - & 24.2 & & \\
\hline 5 & 10 & & $.0 \times 1$ & 5 & .9 & 5.0 & 29 & 9.6 & 45 & 6.3 & 20 & 20 \\
\hline
\end{tabular}

mountain height, which is defined by $N h_{m} / U=$ $l h_{m}$, is 2.6 in this case. In order to display the boundary of the reversal flow zone, the southeasterly velocity component at the lowest level $(z=20 \mathrm{~m})$ is indicated in Figure 3a. Shaded areas indicate the zones of the negative southeasterly velocity component, that is, reversal flow zones which are found both on windward and lee sides.

A band-like convergence zone is clear in Fig. $3 \mathrm{~b}$, in which contours indicate horizontal divergence at $140 \mathrm{~m}$ level. The convergence zone is separated from the mountain base and the maximum of convergence is found just above the boundary of the reversal flow zone at $20 \mathrm{~m}$ level. Fig. $3 \mathrm{c}$ shows the areas of updraft (shaded areas) at $620 \mathrm{~m}$ level. The band-like convergence zone results in an updraft area, which is also organized in a band at $620 \mathrm{~m}$ level.

Figure $3 \mathrm{~d}$ is the vertical cross-section of vertical velocity along 1-21 line shown in Fig. 2a, together with streamlines. Updraft areas in which vertical velocity is greater than $2 \mathrm{~cm} / \mathrm{s}$ are shaded. Mountain airflow exhibits the pattern of gravity wave which propagates vertically. Middle-level updraft areas are tilted upstream and the low-level updraft area is separated from the mountain base. Maximum velocity of windward low-level updraft is about $3.5 \mathrm{~cm} / \mathrm{s}$. Other jump-like updrafts can be found in the lee of the mountain and above the mountain at level around $2000 \mathrm{~m}$.

Figure 4 shows the results of experiment EL10M, in which wind speed of $10 \mathrm{~m} / \mathrm{s}$ is adopted $\left(l h_{m}=1.3\right)$. At the lowest level (Fig. 4a), both windward and lee side areas of reversal flow are 

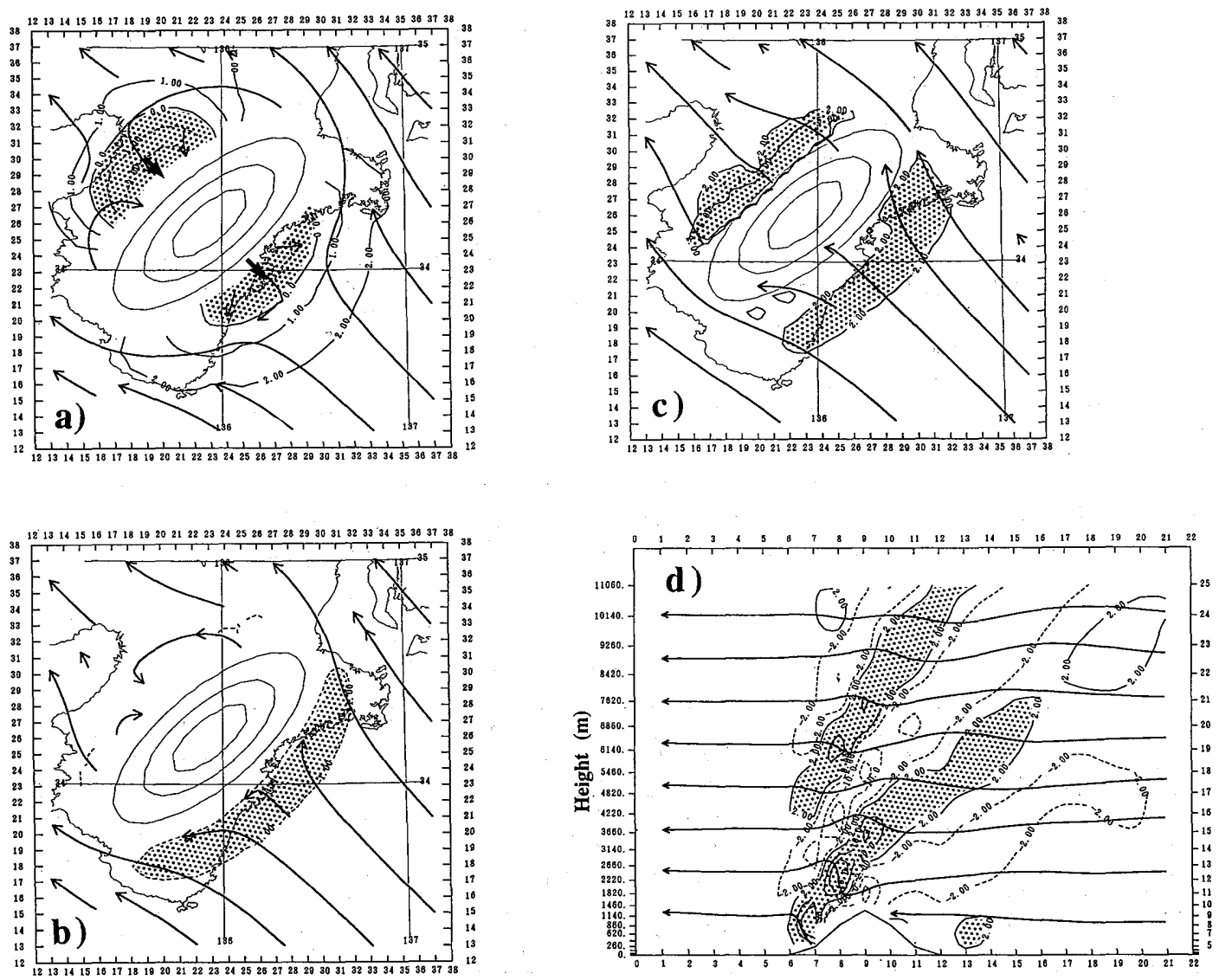

Fig. 3 (a) Streamlines and southeasterly velocity component at $20 \mathrm{~m}$ level obtained by EL05M experiment. Contour interval is $1 \mathrm{~m} / \mathrm{s}$. Shaded areas and heavy arrows indicate the reversal flow zones. (b) Streamlines and horizontal divergence at $140 \mathrm{~m}$ level. Contour interval is $10^{-4} \mathrm{~s}^{-1}$. Shaded area is the windward convergence zone. (c) Streamlines and updraft at $620 \mathrm{~m}$ level. Contour interval is $2 \mathrm{~cm} / \mathrm{s}$. Vertical velocity is larger than $2 \mathrm{~cm} / \mathrm{s}$ in shaded areas. (d) Vertical cross-section of vertical velocity along 1-21 line in Fig. 2a. Contour interval is $2 \mathrm{~cm} / \mathrm{s}$. Vertical velocity is larger than 2 $\mathrm{cm} / \mathrm{s}$ in shaded areas.

smaller in comparison with those in EL05M. The distance from the boundary of the windward reversal flow area to the mountain base is reduced. Figure $4 \mathrm{~b}$ shows the vertical crosssection of vertical velocity. Maximum velocity in the windward low-level updraft area is about $14 \mathrm{~cm} / \mathrm{s}$. The inclination of the updraft area is decreased. The jump-like updraft in the lee of the mountain is seen in this experiment too, while its location shifts leeward. Maximum velocity of the lee side updraft is about $80 \mathrm{~cm} / \mathrm{s}$, which is much greater than that of the low-level windward updraft.

The results of EL15M experiment are shown in Fig. 5. As environmental wind velocity is increased $\left(l h_{m}=0.87\right)$, the area of reversal flow at the lowest level disappears. The vertical cross-section shown in Fig. $5 \mathrm{~b}$ indicates the tendency of more vertically displaced updraft areas. The low-level windward updraft is stronger and is found more closely to the mountain than in the previous experiments. The maximum velocity is about $35 \mathrm{~cm} / \mathrm{s}$ at $2660 \mathrm{~m}$ level. A strong-updraft area with maximum 

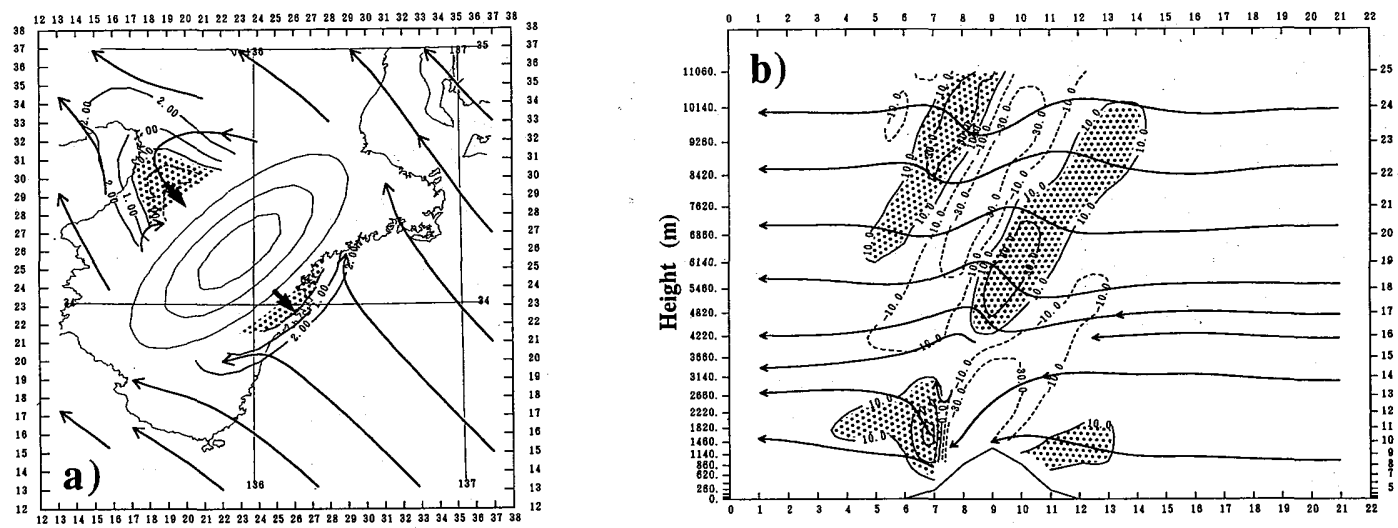

Fig. 4 (a) Same as Fig. 3a but by EL10M experiment. (b) Same as Fig. 3d but by EL10M experiment. Contour interval is $20 \mathrm{~cm} / \mathrm{s}$. Vertical velocity is larger than $10 \mathrm{~cm} / \mathrm{s}$ in shaded areas.


Fig. 5 (a) Same as Fig. 3a but by EL15M experiment. Contour interval is $2 \mathrm{~m} / \mathrm{s}$. (b) Same as Fig. $4 \mathrm{~b}$ but by EL15M experiment. Contour intervals are $20 \mathrm{~cm} / \mathrm{s}$ and $40 \mathrm{~cm} / \mathrm{s}$ in updraft and downdraft areas; respectively. Vertical velocity is larger than $10 \mathrm{~cm} / \mathrm{s}$ in shaded areas.

velocity exceeding $1 \mathrm{~m} / \mathrm{s}$ is found at about 4220 $\mathrm{m}$ level above mountaintop, while it no longer looks like hydraulic jump.

Stronger wind $(20 \mathrm{~m} / \mathrm{s})$ is used in EL20M experiment $\left(l h_{m}=0.65\right)$. The windward lowlevel convergence zone is hardly detected below $260 \mathrm{~m}$ level. At a level as low as $1460 \mathrm{~m}$ shown by Fig. 6a, the windward updraft area and leeward downdraft area form a nearly symmetric pattern. Above the windward slope, the low-level updraft reaches a velocity of $87 \mathrm{~cm} / \mathrm{s}$. The updraft area above the mountain stands more steeply reflecting the large vertical wave length of the mountain wave as shown in Fig. $6 \mathrm{~b}$.

For reference, we show the threedimensional hydrostatic linear analytic solution for a Boussinesq flow over the ellipsoid-shaped mountain Eq. (1). The analytic solution is based on Smith (1980), and is computed using the double Fourier transform (Saito and Ikawa, 1991b). Figures $7 \mathrm{a}$ and $7 \mathrm{~b}$ show the vertical cross-section of vertical velocity by the analytic solution which corresponds to Figs. $4 \mathrm{~b}$ and $6 \mathrm{~b}$. In our case, the analytic solutions along the short axis of the ellipsoid-shaped mountain are somewhat 

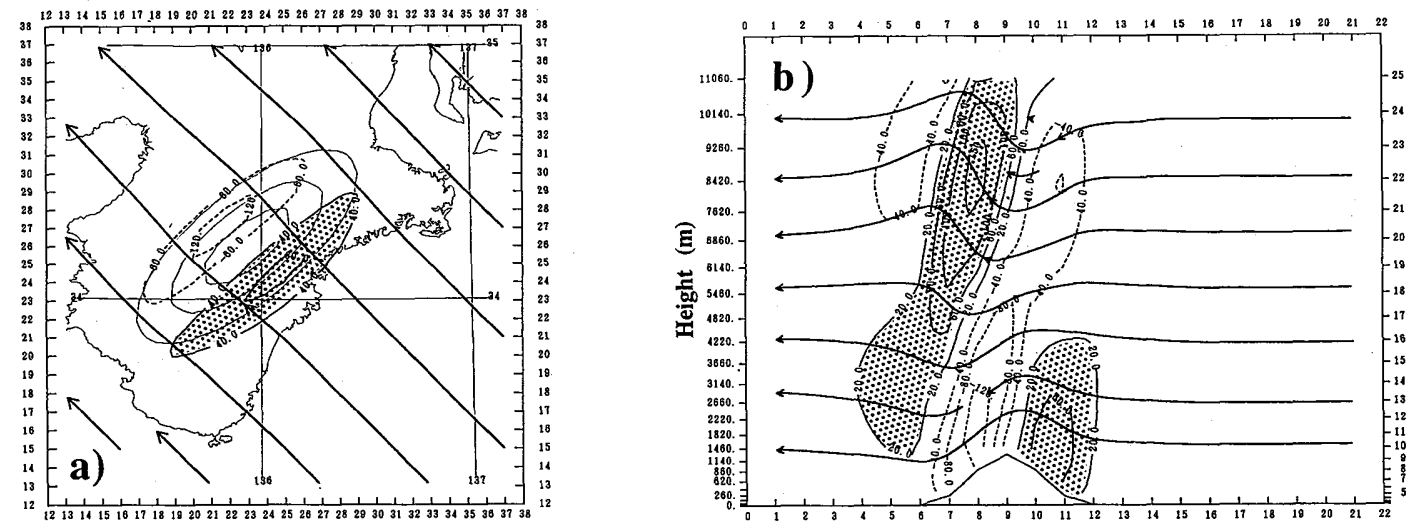

Fig. 6 (a) Streamlines and vertical velocity at $1460 \mathrm{~m}$ level by EL20M experiment. Contour intervals are $40 \mathrm{~cm} / \mathrm{s}$ and $60 \mathrm{~cm} / \mathrm{s}$ in updraft and downdraft areas, respectively. Vertical velocity is larger than $40 \mathrm{~cm} / \mathrm{s}$ in shaded areas. (b) Same as Fig. $4 \mathrm{~b}$ but by EL20M experiment. Contour interval is $40 \mathrm{~cm} / \mathrm{s}$. Vertical velocity is larger than $20 \mathrm{~cm} / \mathrm{s}$ in shaded areas.
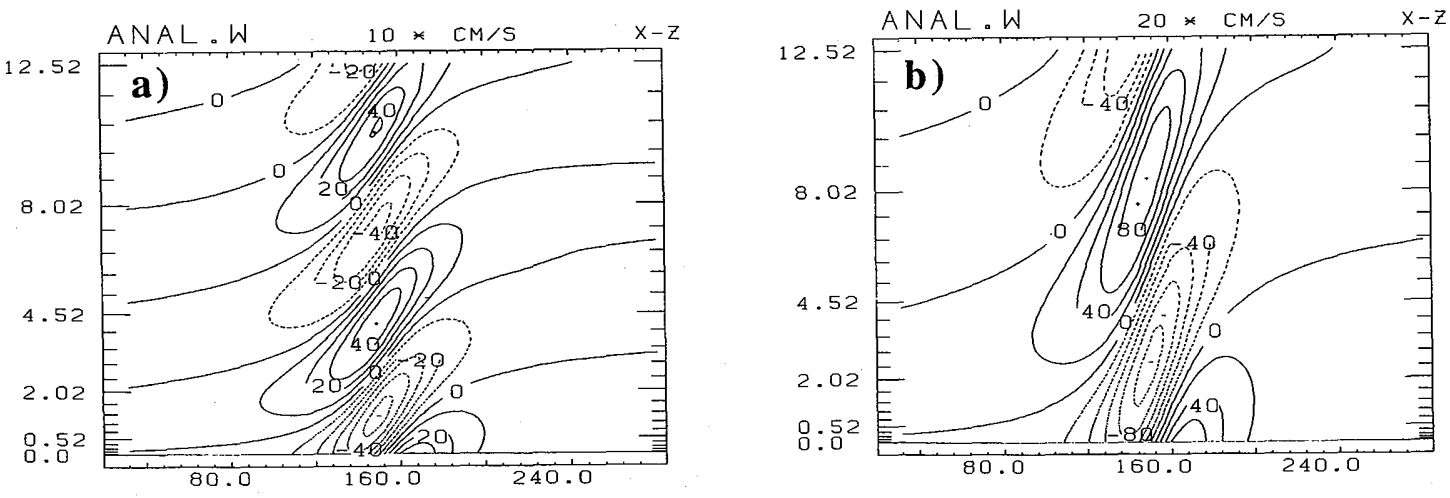

Fig. 7 (a) Vertical cross-section of the vertical velocity by the hydrostatic linear analytic solution of mountain flow over the ellipsoid-shaped mountain (Eq. (1)) along the short axis. For the case of $V=10 \mathrm{~m} / \mathrm{s}, N=0.01 / \mathrm{s}, h_{\mathrm{m}}=1300 \mathrm{~m}, a=72 \mathrm{~km}$ and $b=28 \mathrm{~km}$. (b) Same as (a) but for the case of $V=20 \mathrm{~m} / \mathrm{s}$.

similar to the two-dimensional ones due to the large aspect ratio of the mountain shape $(a / b=$ 18/7). As shown in these figures, the response of vertical velocity field of analytic solution to the variation of wind velocity is quite simple. Except for the amplitude, the vertically propagating mountain waves are only stretched in the vertical direction monotonously by the change of environmental wind.

The response of the simulated updraft area to wind velocity is shown in Fig. 8a. The boundaries of low-level windward updraft areas are shown by thin lines while the axes of the middle-level updraft are indicated by thick ones. The low-level windward updraft area is extended higher and concentrated in a smaller area above the mountain slope in the situation of stronger wind, while in the case of weak wind, the low-level windward updraft area has a tendency to spread away from the mountain base. In the analytic solution shown in Fig. 7, the low-level windward updraft area is confined over the windward slope of the mountain, and does not shift horizontally with changes of wind speed. The simulated middle-level updraft area is stretched vertically in the stronger wind case 

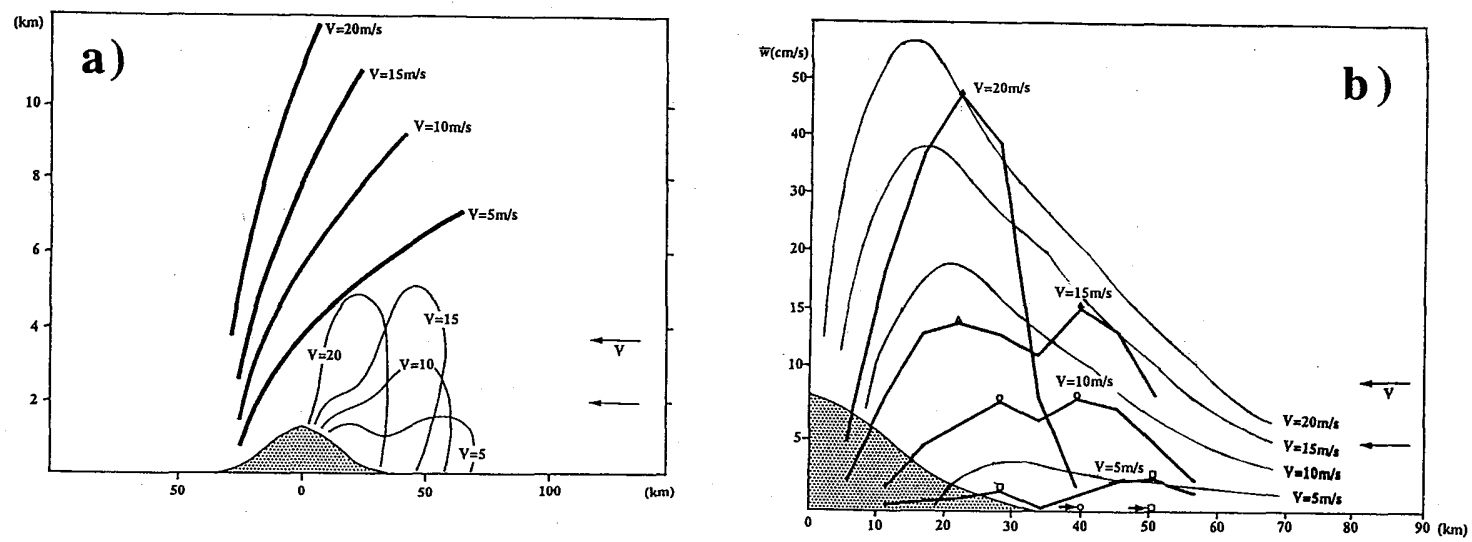

Fig. 8 (a) Sensitivity of mountain-induced updraft to wind velocity. Thin lines indicate the boundaries of low-level updraft areas. Thick lines indicate the axes of middle-level updraft. (b) Updraft velocity averaged in the layer from surface to $1460 \mathrm{~m}$ level along the short axis of the mountain (line 1-21 in Fig. 2a). Thin curves indicate those by analytic solution. Note that the scale of vertical axis varies under $10 \mathrm{~cm} / \mathrm{s}$ and over $20 \mathrm{~cm} / \mathrm{s}$. Circle and square with a thick arrow on the horizontal axis show the positions of the boundary of reversal flow zone in EL10M and EL05M experiments, respectively.
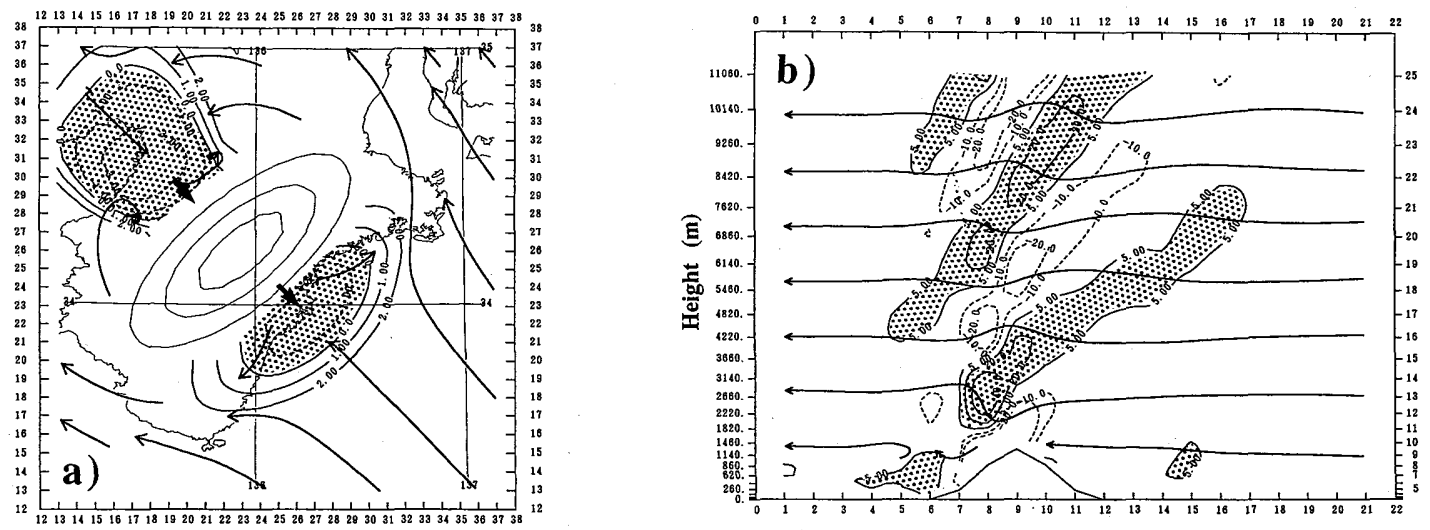

Fig. 9 (a) Same as Fig. 4a but by EL10N experiment. (b) Same as Fig. 4b but by EL10N experiment. Contour intervals are $5 \mathrm{~cm} / \mathrm{s}$ and $10 \mathrm{~cm} / \mathrm{s}$ in updraft and downdraft areas, respectively. Vertical velocity is larger than $5 \mathrm{~cm} / \mathrm{s}$ in shaded areas.

reflecting the increase of vertical wave length of mountain waves. The vertical wave lengths of the simulated mountain waves $\left(\lambda_{z}\right)$ correspond well to the theoretically predicted ones (see Table. 1)

Figure $8 \mathrm{~b}$ indicates averaged updraft velocity in the layer from surface to $1460 \mathrm{~m}$ level along the short axis of the mountain (line 1-21 in Fig. 2b) Thick arrows indicate the boundaries of reversal flow zones by the simulation. In moderate or weak wind cases, the averaged low-level updrafts exhibit two peaks. The first peak is on the windward slope of the mountain, while the second peak is located at the windward edge of the lowest-level reversal flow zones, apparently associated with the low-level blocking by the mountain. The locations of the first updraft $\left(w_{p 1}\right)$ as well as the secondary updraft area $\left(w_{p 2}\right)$ shift upstream as wind velocity decreases. Smolarkiewicz and Rotunno (1990) also point out the same tendency in their study on the reversal flow zone by their ideal numerical simulation, but the surface friction and diffusion also contribute to the low-level blocking in our experiments. The strength of updraft is dependent on wind velocity. The 


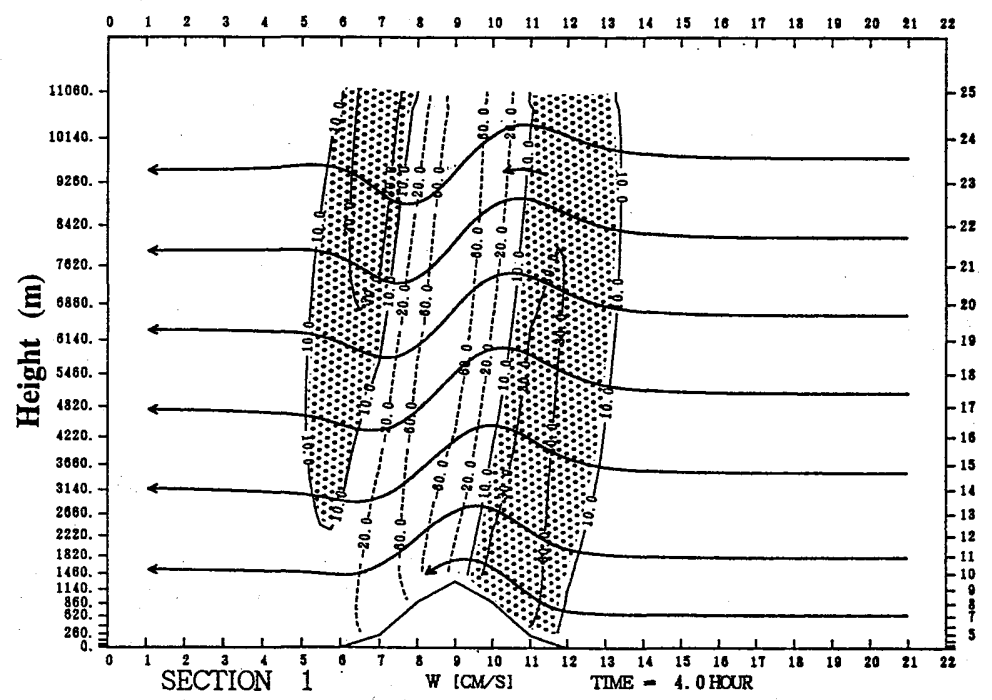

Fig. 10 Same as Fig. 5b but by EL10L experiment.
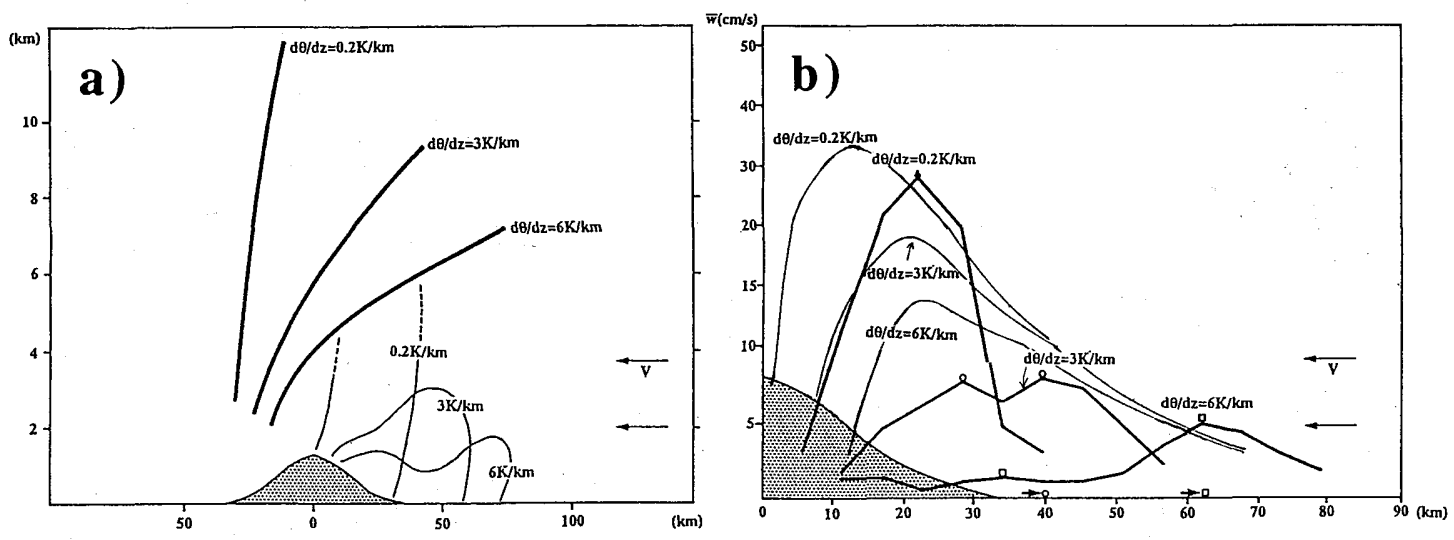

Fig. 11 Same as Fig. 8 but sensitivity to thermal stability.

updraft over the windward slope of the mountain $\left(w_{m 1}\right)$ decreases as wind becomes weaker, while the secondary peak $\left(w_{m 2}\right)$ becomes evident. In analytic solution, although the locations of the peaks of the averaged low-level updrafts shift windward with the decrease of the wind speed by the increase of wave number in the averaging area, the secondary peak never appears.

\subsection{Sensitivity of mountain flow to thermal stability}

In this sub-section, response of mountain flow to thermal stability is studied by sensitivity experiments. Figure 9a shows the lowest flow pattern by an experiment, in which wind speed of $10 \mathrm{~m} / \mathrm{s}$ and potential temperature lapse rate of $6 \mathrm{~K} / \mathrm{km}$ are used (EL10N). The nondimensional mountain height $l h_{m}$ in this case is 1.8. Both windward and lee side areas of reversal flow are larger than those in EL10M experiment. The boundary of the windward reversal flow zone is located at a distance of about $60 \mathrm{~km}$ from the mountaintop, farther by about $20 \mathrm{~km}$ than in EL10M. It results in farther displacement of the convergence zone at $140 \mathrm{~m}$ level and the updraft area at $620 \mathrm{~m}$ level. The inclination of the middle-level updraft area is increased as shown in Fig. 9b.

In the case of reduced thermal stability 0.2 

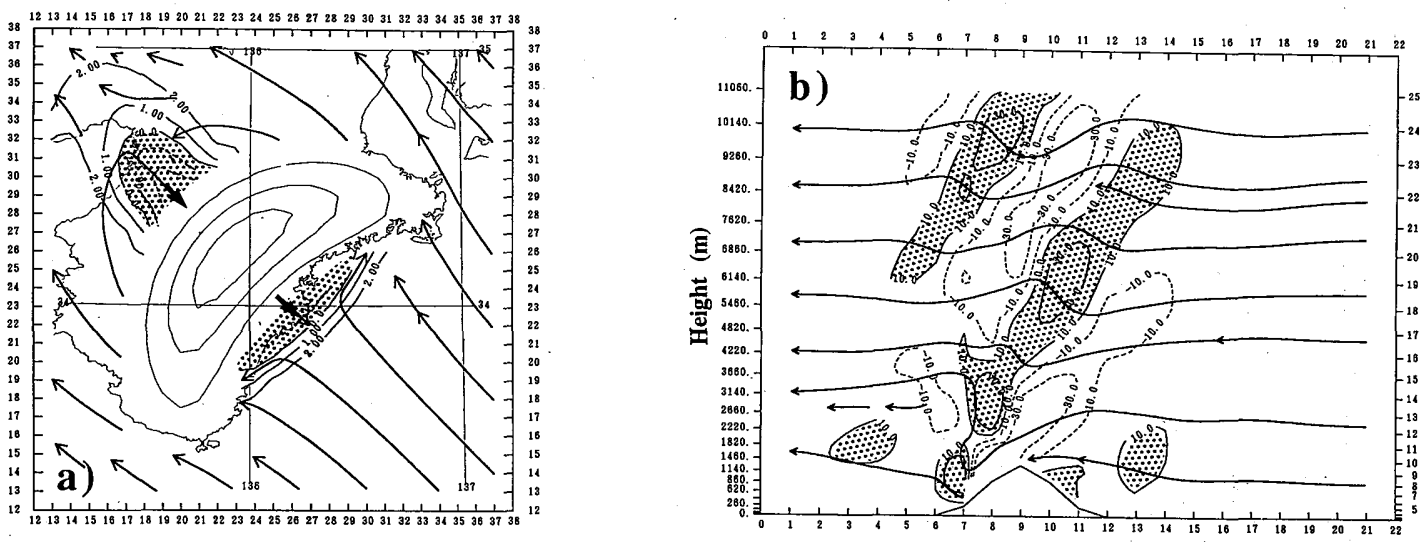

Fig. 12 (a) Same as Fig. 4a but by CE10SE experiment. (b) Same as Fig. 4b but by CE10SE experiment and vertical cross-section along 1-21 line in Fig. 2b.

$\mathrm{K} / \mathrm{km}$ (EL10L experiment; $\left.l h_{m}=0.34\right)$, the whole updraft is concentrated above the upwind slope due to the large vertical wave length (see Table 1). The nearly upright areas of updraft and downdraft, which are similar to the potential flow and easily predicted by linear theory, can be found in the vertical cross-section of Fig. 10.

Figure 11 summarizes the sensitivity of mountain airflow to thermal stability. In a less stable atmosphere, the low-level windward updraft is concentrated in a smaller and higher extended area above the mountain slope and the axis of the middle-level updraft is more vertical (Fig. 11a). When the atmosphere is more stable, the reversal flow is stronger and spreads farther upstream (Fig. 11b). The strength of updraft is dependent on thermal stability and decreases as it increases. In EL10N experiment, the nondimensional mountain height $l h_{m}$ is 1.8 , and is less than that in EL05M, but vertical velocity at the windward secondary peak $\left(w_{m}^{2}\right)$ is much greater than that in EL05M by virtue of the relatively strong wind. In Fig. 11b, the averaged low-level updraft is seemingly discrepant between EL10L and analytic solution despite the small $l h_{m}(0.34)$. The difference is attributable to the surface friction included in the simulation.

\subsection{Case for a curved ellipsoid mountain shape}

In order to examine the effect of the mountain shape on airflow, a numerical experiment for curved ellipsoid-shaped mountain (Fig. $2 \mathrm{~b}$ ) is conducted. Atmospheric conditions in this experiment are the same as in EL10M, that is, $V=10 \mathrm{~m} / \mathrm{s}$ and $d \theta / d z=3 \mathrm{~K} / \mathrm{km}$. This experiment is named CE10SE.

Figure 12a shows the lowest flow pattern by CE10SE experiment. The curved mountain shape results in farther upstream displacement of the boundary of the reversal flow zone. The same tendency of displacement can be detected in the convergence zone at $140 \mathrm{~m}$ level and the updraft area at $620 \mathrm{~m}$ level. The secondary updraft is more clearly separated from the mountain slope, as shown in Fig. 12b. The arrangement of updraft and downdraft at upper levels is similar to that in EL10M experiment. As seen in Fig. 13, the windward updraft is stronger and shifted farther upstream in the case of a curved-ellipsoid mountain. In analytic solution, the difference between the curved and non-curved mountain is very small since the cross-section of the mountain along the shorter axis is the same shape between them.

By CE10E experiment, in which the wind direction is easterly, the windward reversal flow zone is not seen at $20 \mathrm{~m}$ level. The streamlines in the vicinity of the mountain base have a 


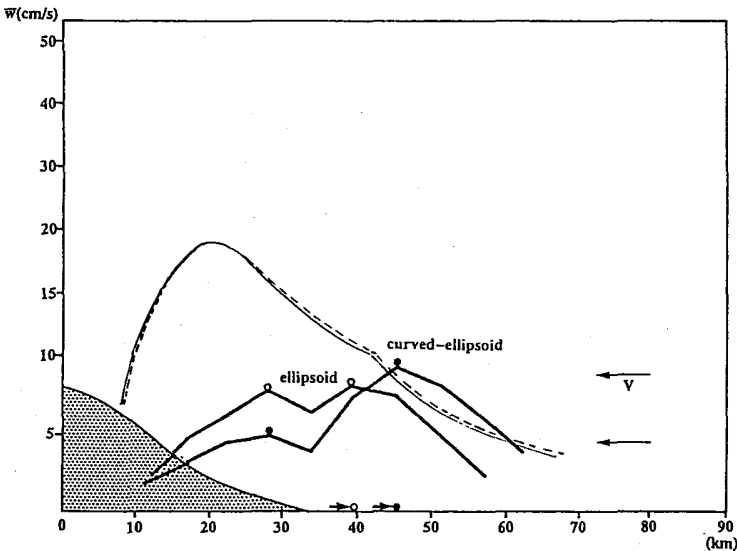

Fig. 13 Same as Fig. 8 but sensitivity to mountain shape. Pecked curve indicates analytic solution for curved-ellipsoid shaped mountain.

tendency to go along the mountain base and form a tail-shaped convergence zone at $140 \mathrm{~m}$ level (Fig. 14). The area of updraft at $620 \mathrm{~m}$ level also has a tail, which is separated from the mountain slope (figure not shown).

Numerical experiments on a curvedellipsoid shaped mountain show that the curvature of the mountain range has an influence on mountain flow at low levels. Even if the wind direction is not perpendicular to the longer axis of the mountain, the low-level convergence zone and updraft area associated with it are located farther upstream.

\section{Flow over the Kii peninsula}

\subsection{Brief analysis of rainfall in the Kii peninsula in 1985}

In order to detect the features of horizontal rainfall distribution in the case of heavy rain, AMeDAS data in 1985 are analyzed briefly. Sakakibara and Takeda (1973) stated that the total rainfall amount at each weather station is heavily dependent on the topographic features near the station, while the time variation of rainfall can reflect the traveling of convective precipitating clouds. In our study, Owase station is selected as a typical one where the rainfall amount is much enhanced by orographic effect, while Shionomisaki station is selected as a station close by where orographic effect on

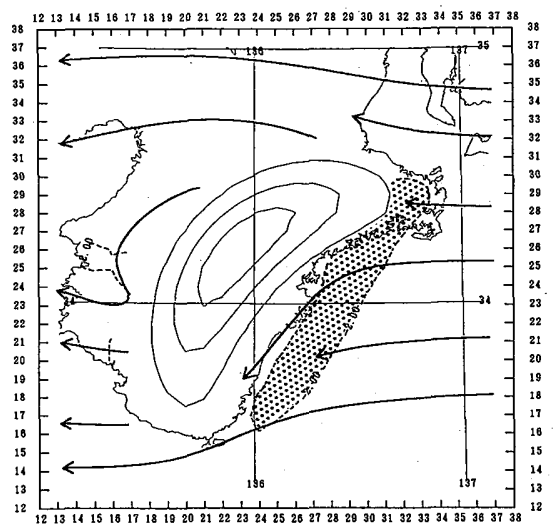

Fig. 14 Streamlines and divergence at $140 \mathrm{~m}$ level by $\mathrm{CE} 10 \mathrm{E}$ experiment. Contour interval is $2 \times 10^{-4} \mathrm{~s}^{-1}$. Shaded area indicates the windward convergence zone.

rainfall seems to be relatively small.

Figure 15 shows the relationship between daily rainfall amounts at Owase and Shionomisaki in 1985. As our attention is paid chiefly to heavy rain, only cases of daily rainfall larger than $50 \mathrm{~mm}$ are plotted. Obviously the rainfall amount observed at Owase is higher in many cases than that observed at Shionomisaki. Cases where the daily rainfall amount at Owase is greater than $100 \mathrm{~mm}$ and the difference in rainfall between the two stations is greater than $50 \mathrm{~mm}$, are indicated by large black dots together with the dates of observations.

As pointed out by Takeda et al. (1976), heavy rains are often observed around Owase when easterly to southeasterly wind is prevalent at low levels. Heavy-rain cases in 1985 are not exceptions, as shown in Fig. 16. In this figure, the daily prevalent wind direction at the surface is expressed by the direction of each point to the center of circles, and the daily rainfall amount is indicated by the distance of each point from the center of circles. Most of the heavy-rain cases at Owase are found in the second quarter. In other words, heavy rain at Owase occurred in the situation of easterly to southeasterly lowlevel wind.

As the next step, GMS histogram data are used to calculate averaged TBB (equivalent black-body temperature) of cloud tops in the square of $0.25^{\circ}$ longitude $\times 0.25^{\circ}$ latitude. Figure 17 


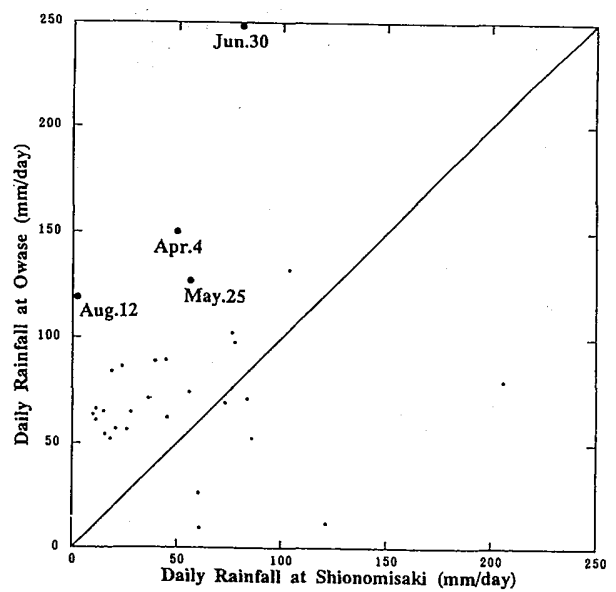

Fig. 15 Relationship between daily rainfall amounts at Owase and at Shionomisaki in 1985.

(a)





Fig. 16 Daily rainfall-prevalent wind hodograph.

(b)

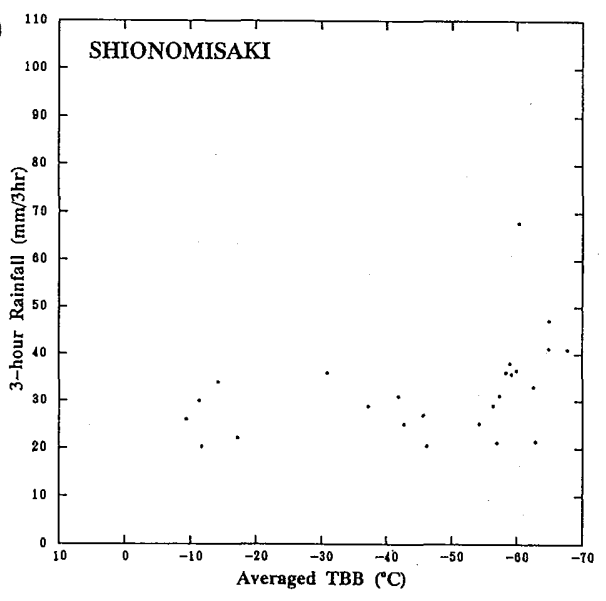

Fig. 17 (a) Relationship between 3-hour rainfall and averaged TBB at Owase. (b) Same as (a) but at Shionomisaki.
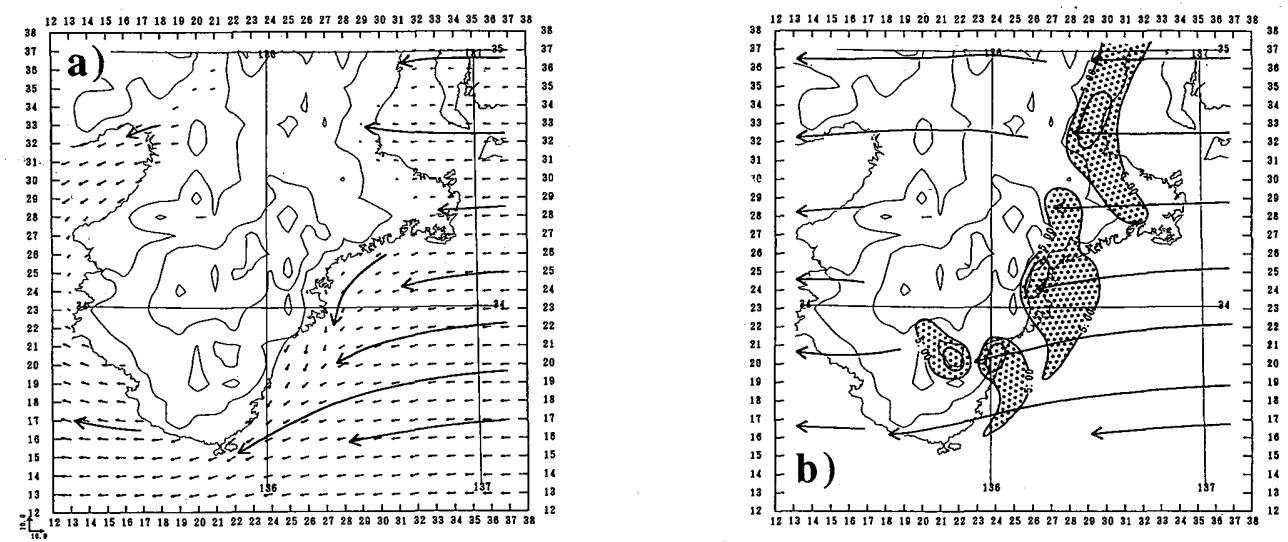

Fig. 18 (a) Streamlines and wind vectors at $20 \mathrm{~m}$ level by E experiment. (b) Streamlines and updraft averaged in the layer from surface to $1460 \mathrm{~m}$ level. Contour interval is $5 \mathrm{~cm} / \mathrm{s}$. Vertical velocity is larger than $5 \mathrm{~cm} / \mathrm{s}$ in shaded areas. 

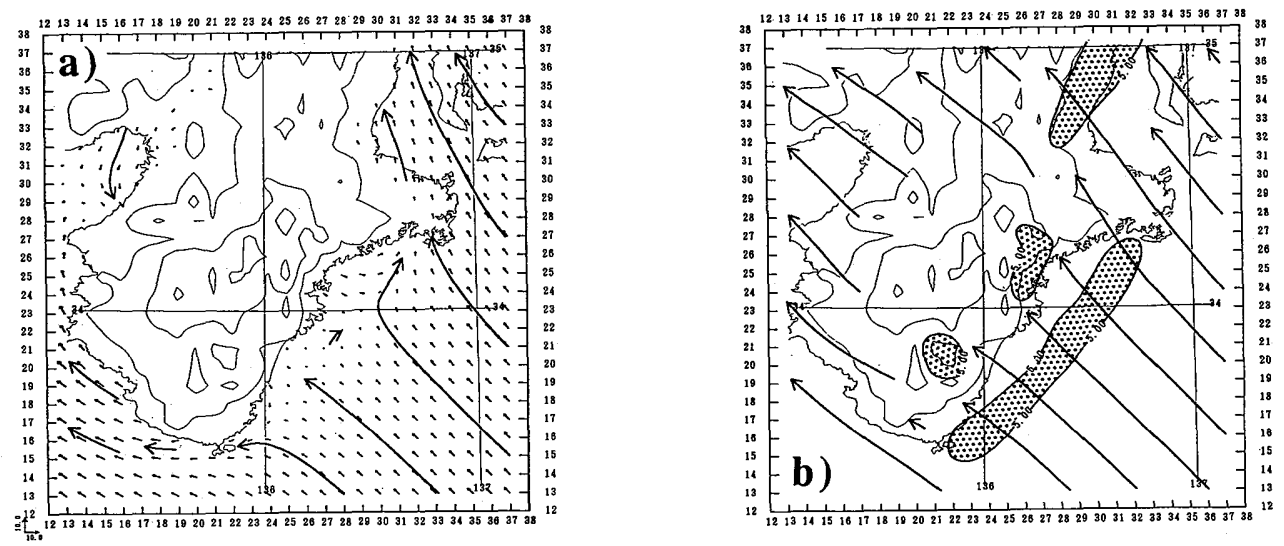

Fig. 19 Same as Fig. 18 but by SE experiment.

indicates the relationship between 3-hour rainfall and averaged TBB computed in the square in which Owase station (a) or Shionomisaki station (b) is located. Only the cases of 3-hour rainfall greater than $20 \mathrm{~mm}$ are plotted. Even clouds which are not so deep can produce heavy rainfall at Owase while such clouds can not be found at Shionomisaki.

On the basis of brief analyses described above, four cases of April 4, May 25, June 30 and August 12 are selected for further study. The horizontal distribution of 3-hour rainfall in the period of the most intensive rain at Owase will be compared with numerically simulated flow in sub-section 4.3

\subsection{Flow over the Kii peninsula for simplified atmospheric conditions}

In the previous section, we examined the sensitivity of mountain flow to atmospheric conditions in the case of ellipsoid and curvedellipsoid mountains. As the topography in the Kii peninsula has many complex features, numerical experiments in the situation of simplified atmospheric conditions will be made first to investigate the effect of real mountains on airflow. All the experiments in this sub-section are initiated with non-shear wind of $10 \mathrm{~m} / \mathrm{s}$ and a constant lapse rate of potential temperature of $3 \mathrm{~K} / \mathrm{km}$. Only the wind direction is a variable parameter and changes from easterly to westerly (E,SE,S,SW,W). Cases of experiments are named $\mathrm{E}, \mathrm{SE}, \mathrm{S}, \mathrm{SW}$ and $\mathrm{W}$, respectively.

Figure 18a shows the wind pattern at the surface in the case of easterly wind ( $E$ experiment). Many similarities can be found between this pattern and the result of $\mathrm{CE} 10 \mathrm{E}$ experiment (Fig. 14), in which a curvedellipsoid shaped mountain was used. In the vicinity of a mountain base, airflow at the surface tends to go along the seashore line and convergence zone is formed at low levels separately from the mountain base. However, some differences also exist. Figure $18 \mathrm{~b}$ shows the horizontal pattern of updraft averaged in the layer from surface to $1460 \mathrm{~m}$ level. The maximum of the low-level updraft is found on the windward side of a high mountain around Owase. Other low-level updraft areas can be found in the northern and southern parts of the Kii peninsula. Also in the case of real topography low-level updraft areas are formed over the sea and the updrafts in their areas are stronger than those in the case of idealized topography.

The results of SE experiment are shown in Fig. 19. Reversal flow is formed in this case as shown in Fig. 19a. In comparison with the case of CE10SE shown in Fig. 12, the boundary of the reversal flow zone and convergence zone associated with it are found farther upstream. Consequently, the windward updraft area is located over the sea far from the land (Fig. 18b). Apparently, this band-like updraft area over the sea 

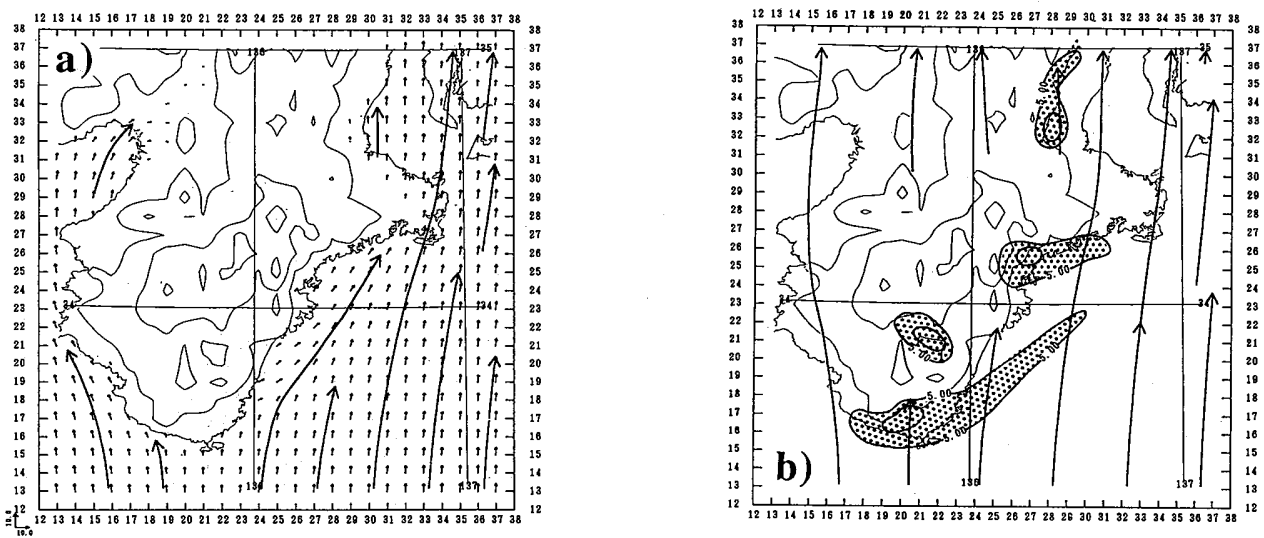

Fig. 20 Same as Fig. 18 but by S experiment.
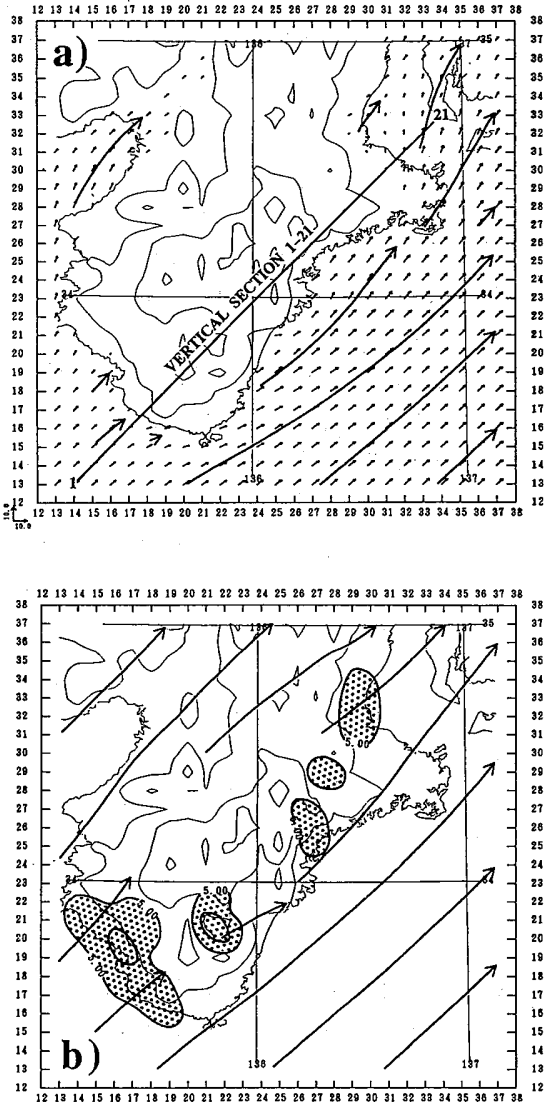

is associated with the windward secondary updraft due to low-level blocking shown in Section 3. Other updraft areas can be found around Owase and in the northern and southern parts of the Kii peninsula.

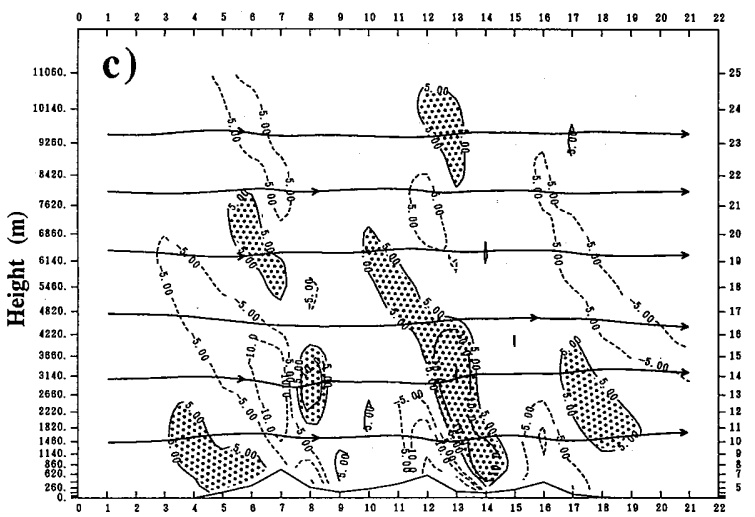

Fig. 21 (a), (b) Same as Fig. 18 but by SW experiment. (c) Vertical cross section of vertical velocity along 1-21 line in (a). Contour interval is $5 \mathrm{~cm} / \mathrm{s}$. Vertical velocity is larger than $5 \mathrm{~cm} / \mathrm{s}$ in shaded areas.

Figure 20 indicates surface airflow (a) and low-level averaged updraft (b) in the case of southerly wind (S experiment). A low-level updraft area is seen over the sea in this case too, but not so conspicuously as in Fig. 19b. Surface streamlines in Fig. 20a do not show so strong blocking as in Fig. 19a. An interesting fact revealed from the $\mathrm{E}, \mathrm{SE}$ and $\mathrm{S}$ experiments is that two updraft areas always exist in the area around Owase and in the southern part of the Kii peninsula in the situation of easterly, southeasterly and southerly winds.

The results of SW and W experiments are shown in Figs. 21 and 22 respectively. When wind 

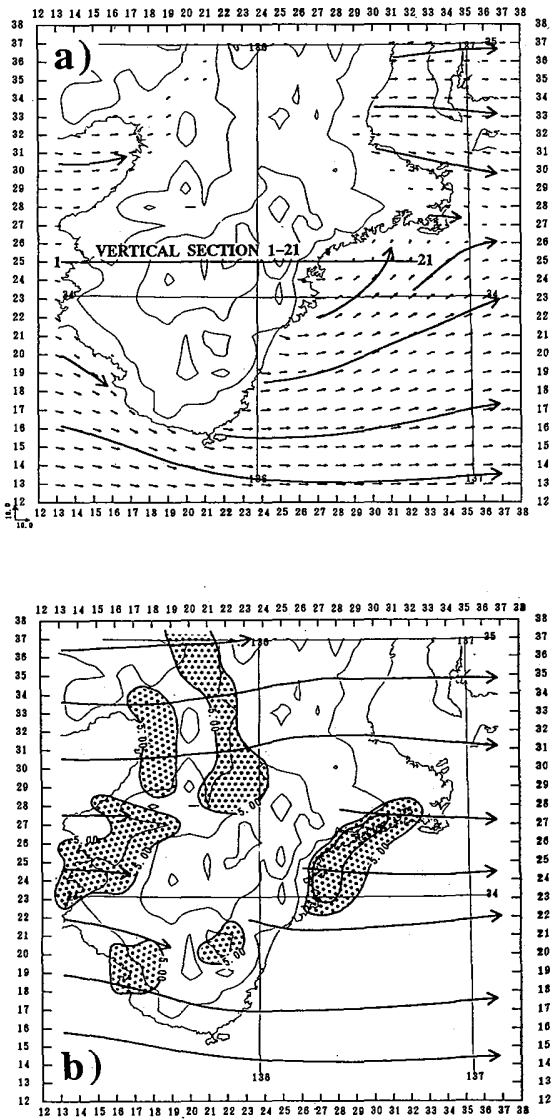

is southwesterly or westerly, windward low-level updraft areas are located over the land, in contrast with previous $\mathrm{E}, \mathrm{SE}$ and $\mathrm{S}$ experiments, in which they were found over the sea: As seen in Figs. 21a and 22a, surface streamlines no longer exhibit low-level blocking. Updrafts can be found around Owase (Figs. 21b and 22b), but in this situation they are lee side updrafts as shown in vertical cross-sections (Figs. 21c and 22c).

From previous studies on rainfall in the Kii peninsula and brief analyses of rainfall in 1985, it is clear that heavy rains are often observed in the situation of easterly, southeasterly or southerly wind at low levels. In this situation the results of the present numerical experiment show that the distribution of low-level updraft areas has some characteristic features. The first is the existence of a windward updraft area over the sea, which results from the low-level blocking by the mountain. The curved shape of the windward

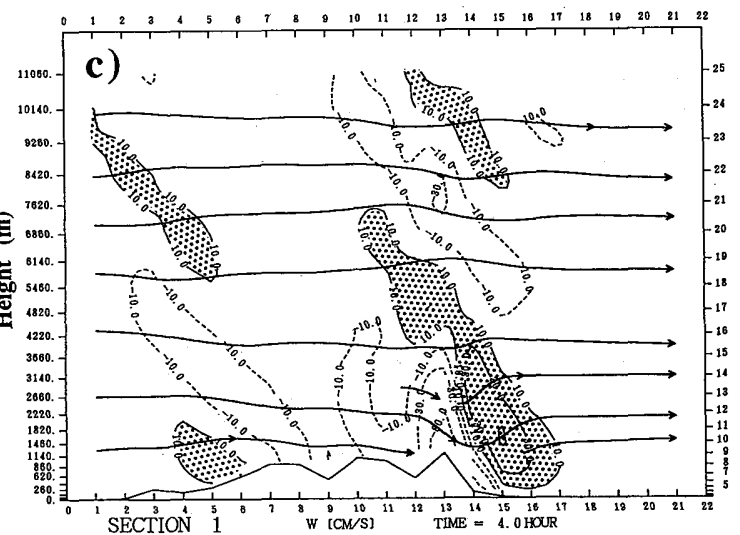

Fig. 22 (a),(b) Same as Figs. 21a, b but by W experiment. (c) Vertical cross-section of vertical velocity along 1-21 line in (a). Contour interval is $20 \mathrm{~cm} / \mathrm{s}$. Vertical velocity is larger than $10 \mathrm{~cm} / \mathrm{s}$ in shaded areas.

slope of mountains along the southeastern seashore in the Kii peninsula contributes to the blocking. A band-shaped convective rain area is often observed along this area in the situation of weak wind (Takeda and Takase, 1980). The other one is two maxima of updraft in the area around Owase and in the southern part of the Kii peninsula. Two maxima can be formed even in the situation of southwesterly or westerly wind on the lee side of a mountain. The steep slope of mountains can cause the formation of these updrafts. It is interesting that the positions of the above-mentioned updrafts are well coincident with the positions of two maxima in the mean annual rainfall distribution shown by Sakakibara and Takeda (1973).

\subsection{Flow over the Kii peninsula for observed wind profile in heavy-rain events}

In this subsection, we conduct numerical experiments using observed atmospheric conditions in heavy-rain events in 1985 shown in subsection 4.1. Although both observed wind and thermal profiles are used for the environmental field, our interest is only in the response of the low-level updraft to the variation of wind direction and speed. Since the model omits cloud 


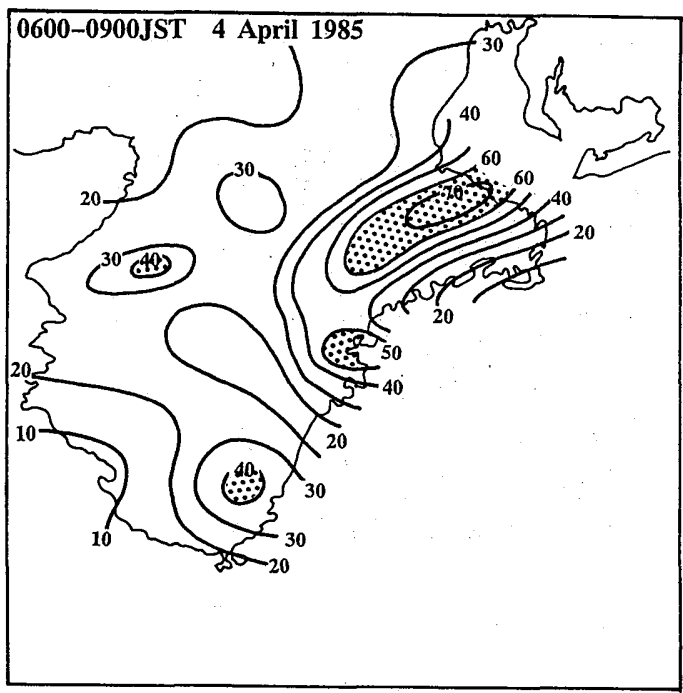

Fig. 23 The distribution of 3-hour rainfall from 0600 to $0900 \mathrm{JST}$ on 4 April. Shaded areas indicate local maxima of rainfall.



Fig. 24 Atmospheric profile at 0900 JST on 4 April at Shionomisaki. Solid line indicates temperature profile. Dashed line indicates the profile of relative humidity.

of the mountains. Two local maxima are found in the area around Owase and in the southern most part of the peninsula (shaded areas). Another feature of rainfall distribution is a band-like heavy rain zone located to the north of Owase in spite of smooth topography around this area. Figure 24 shows 0900 JST sounding at Shionomisaki. Wind was nearly southerly at the surface and southwesterly at middle levels.

Figure 25 shows the result of the numerical experiment in which observed atmospheric conditions are used. The wind pattern and streamlines (Fig. 25a) show similar features to the result of $\mathrm{S}$ experiment (Fig. 20a). The windward convergence zone at $140 \mathrm{~m}$ level is located over the sea, resulting in the secondary updraft area at $420 \mathrm{~m}$ level (Fig. 25b). Two maxima of updraft which are formed around Owase and in the southernmost part of the peninsula. Updraft averaged in the layer from $2600 \mathrm{~m}$ to $4220 \mathrm{~m}$ is shown in Fig. 25c. The area of updraft is formed on the lee side of the mountain in consideration of the wind direction at middle intensive rain occurred along the southeastern slope 

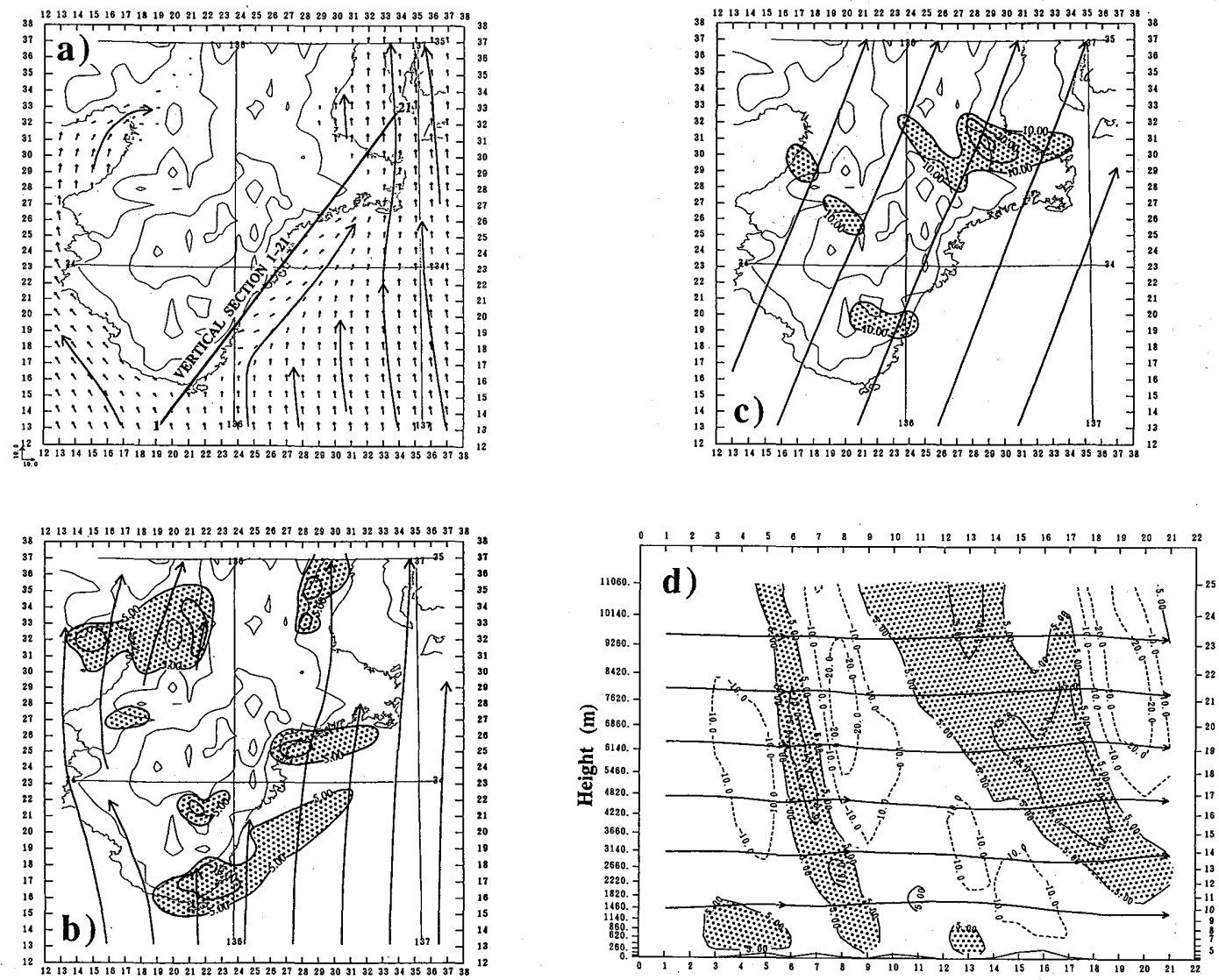

Fig. 25 (a) Same as Fig. 18a but by 4 Ápril experiment. (b) Streamlines and updraft at $420 \mathrm{~m}$ level. Contour interval is $5 \mathrm{~cm} / \mathrm{s}$. Vertical velocity is larger than $5 \mathrm{~cm} / \mathrm{s}$ in shaded areas. (c) Streamlines and updraft averaged in the layer from $2600 \mathrm{~m}$ to $4220 \mathrm{~m}$ level. Contour interval is $10 \mathrm{~cm} / \mathrm{s}$. Vertical velocity is larger than $10 \mathrm{~cm} / \mathrm{s}$ in shaded areas. (d) Vertical cross-section of vertical velocity along $1-21$ line in (a). Contour interval is $10 \mathrm{~cm} / \mathrm{s}$. Vertical velocity is larger than $5 \mathrm{~cm} / \mathrm{s}$ in shaded areas.

levels. The position of the lee side updraft area is more clearly shown in vertical section of Fig. $25 \mathrm{~d}$. It is to be noted that middle-level clouds covered the Kii peninsula at this time and the location of simulated middle-level updraft is coincident with the position of the intensive rain area.

\section{b) Case of May 25}

The distribution of three-hour rainfall in the period from 0300 to 0600 JST on May 25 is shown in Fig. 26. Daily rainfalls at Owase and Shionomisaki are $126 \mathrm{~mm}$ and $56 \mathrm{~mm}$, respectively. Horizontal rainfall distribution in this case is analogous to the case of April 4. The local maxima of rainfall are located around Owase and the southernmost part of the peninsula. Another band-like heavy rainfall area is also observed to the north of Owase.

Figure 27 shows 0300 JST sounding at Shionomisaki. Wind direction was SSE at the surface and SSW $25 \mathrm{~m} / \mathrm{s}$ at $400 \mathrm{mb}$ level. Apparently atmospheric conditions on May 25 were similar to those on April 4.

Airflow at $20 \mathrm{~m}$ level (Fig. 28a) and low-level updraft areas (Fig. 28b) show nearly the same features as in the case of April 4. The distribution 


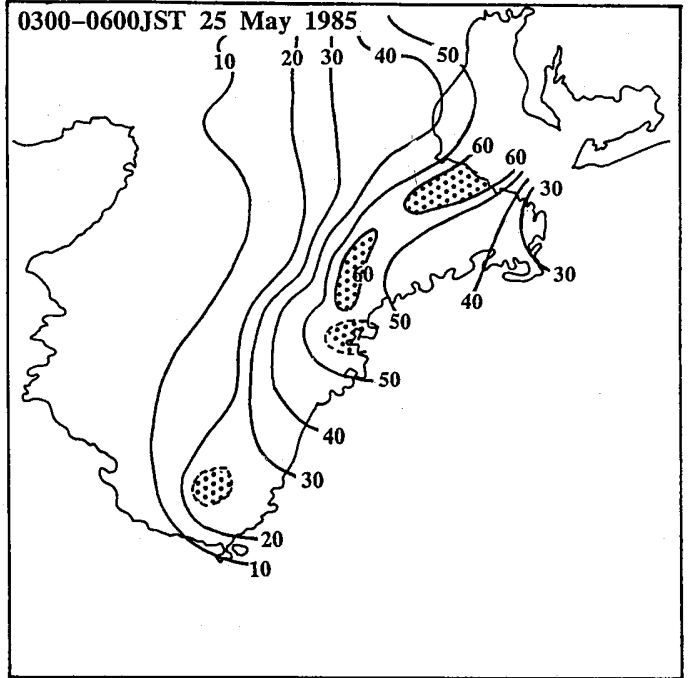

Fig. 26 Same as Fig. 23 but from 0300 to 0600 JST on 25 May.

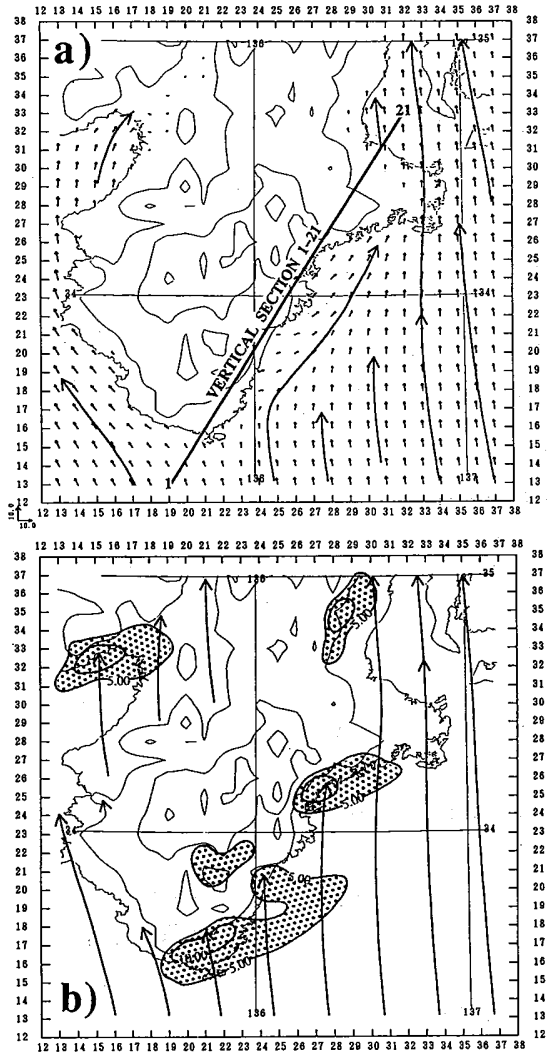



Fig. 27 Same as Fig. 24 but at 0300 JST on 25 May.
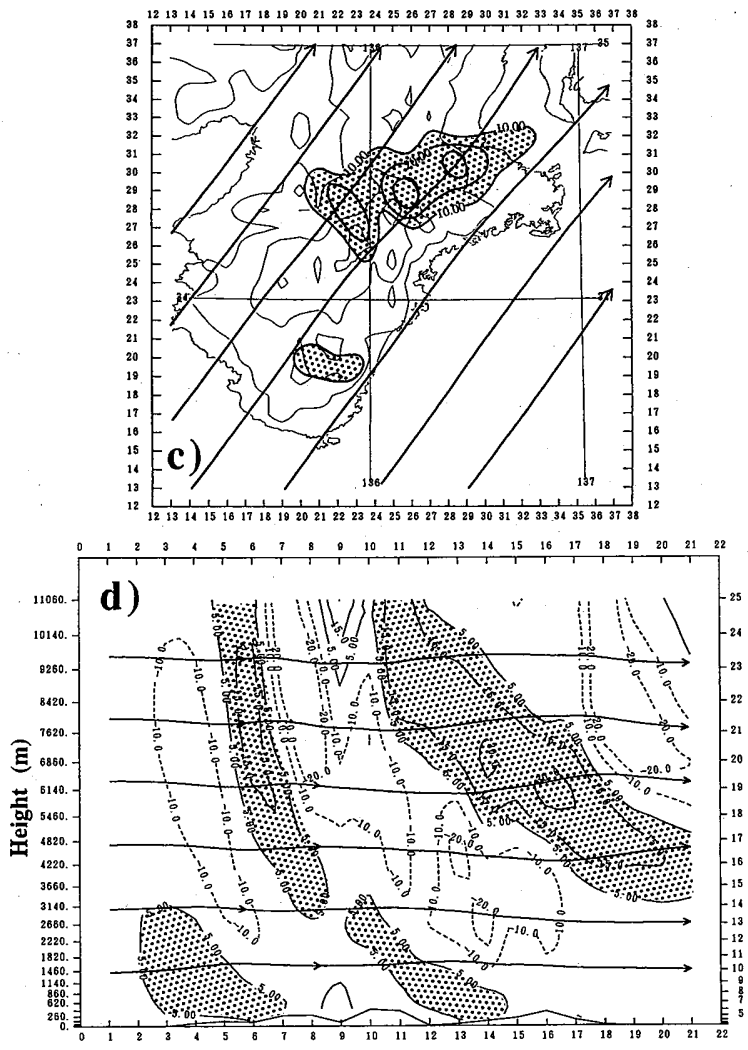

Fig. 28 (a), (b) Same as Figs. 25a and 25b but by 25 May experiment.(c) Same as Fig. 25c but by 25 May experiment. Streamlines and updraft averaged in the layer from $3600 \mathrm{~m}$ to $5460 \mathrm{~m}$ level. (d) Same as Fig. 25d but by 25 May experiment. 
of low-level updraft areas are well coincident with rainfall distribution in the area around Owase and in the southernmost part of the peninsula. Although the middle-level updraft area on the lee side of the mountain is found higher (Fig. 28d), this area is also located just above the heavy rain band north of Owase (Fig. 28c).

\section{c) Case of June 30}

On June 30, Typhoon 8506 (Irma) attacked the Kii peninsula and intensive rain occurred in a larger area in the Kii peninsula. Daily rainfall was $249 \mathrm{~mm}$ at Owase, which is the largest among selected cases in 1985, but it was only $81 \mathrm{~mm}$ at Shionomisaki. The distribution of three-hour rainfall (Fig. 29) shows two-maxima: one is around Owase, the other is in the southern part of the peninsula. This pattern differs from the previous two cases, in which rainfall was concentrated along the seashore.

Sakakibara and Takeda (1973) noted that the distribution of total rainfall during the typhoon passage resembles the distribution of mean annual rainfall. In other words, heavy-rain areas are located farther inland, as seen in the rainfall distribution of June 30 case.

Figure 30 shows 2100 JST sounding at Shionomisaki. Strong easterly to southeasterly wind was observed throughout low and middle levels. Maximum wind velocity was $37 \mathrm{~m} / \mathrm{s}$ at 900 $\mathrm{mb}$ level. Atmospheric conditions of this day were characterized by very strong wind.

Figure 31 shows the computational result of June 30 case. Even the lowest wind (Fig. 31a) does not flow around mountains. Although the computed updraft is still located on the windward side compared to the observation, strong updraft areas are formed on the eastern slope of the mountain around Owase and in the southern part of the peninsula (Fig. 31b). As shown in the sensitivity experiments of section 3 in the situation of strong wind (experiment EL20M), the updraft area was more vertical and concentrated in the area above the windward slope of the mountain and no secondary updraft appeared. The same tendency can be seen in vertical cross-section shown in Fig. 31c. The shift of the updraft area from offshore region to the windward slope and the concentration of intensive updraft contribute to the change in the horizontal distribution of rainfall in the case of strong wind.

\section{d) Case of August 12}

On August 12, heavy rainfall was observed mainly in the area around Owase (Fig. 32). In addition, two other local maxima of rainfall were located to the north of Owase and in the southern part of the peninsula. The horizontal distribution of rainfall is similar to those in April 4 and May 25 cases (Figs. 23 and 26). According to 0300 JST sounding at Shionomisaki (Fig. 33), wind direction was SSE at the surface and SSW at upper levels.

Computational results are represented in Fig. 34. The airflow pattern at the surface (Fig. 34a) exhibits the same features as in April 4 and May 25 cases (Figs. 24a and 27a). Because of weaker wind, low-level convergence is weaker than in the previous cases. At $420 \mathrm{~m}$ level updraft areas are at the same location as in April 4 and May 25 cases (Fig. 34b). Again, the middle-level updraft area associated with the mountain waves can be seen in Figs. $34 \mathrm{c}$ and $34 \mathrm{~d}$.

\section{Discussion}

It is evident that th e enhancement of rainfall by orographic effect is primarily related to the characteristic features of the flow around the mountains. If the air thus lifted is sufficiently moist, orographic clouds can be formed on the windward side of the mountain. The generation of precipitating clouds in this way is one of the contributing factors in the enhancement of rainfall in the mountainous region. In other situations, flow over mountains has an influence on a traveling precipitating cloud system and causes the enhancement of rainfall in the vicinity of mountains. These processes - the formation of orographic precipitating clouds and the orographic enhancement of rainfall originated 


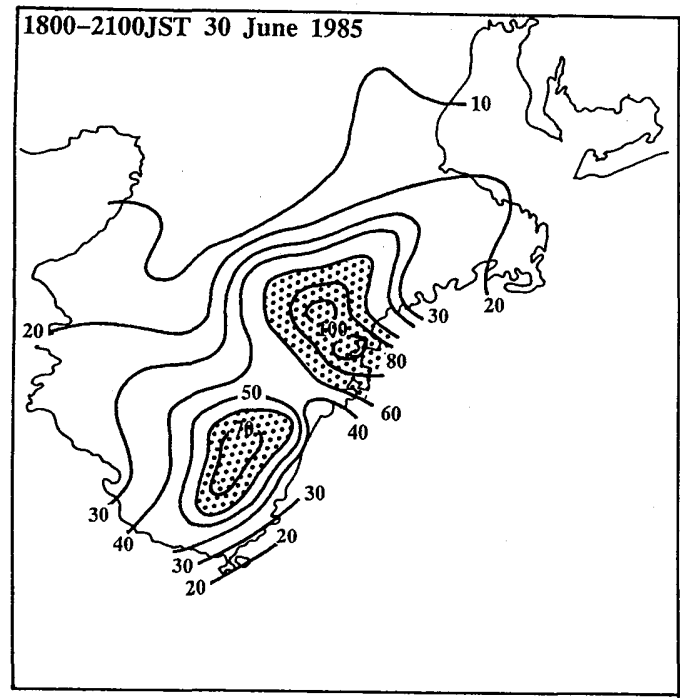

Fig. 29 Same as Fig. 23 but from 1800 to 2100 JST on 30 June.

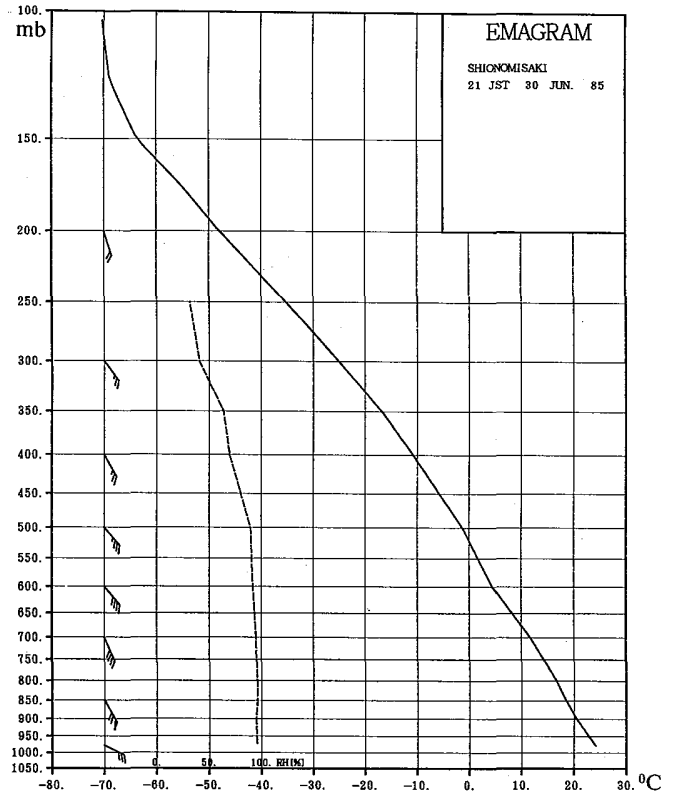

Fig. 30 Same as Fig. 24 but at 2100 JST on 30 June.
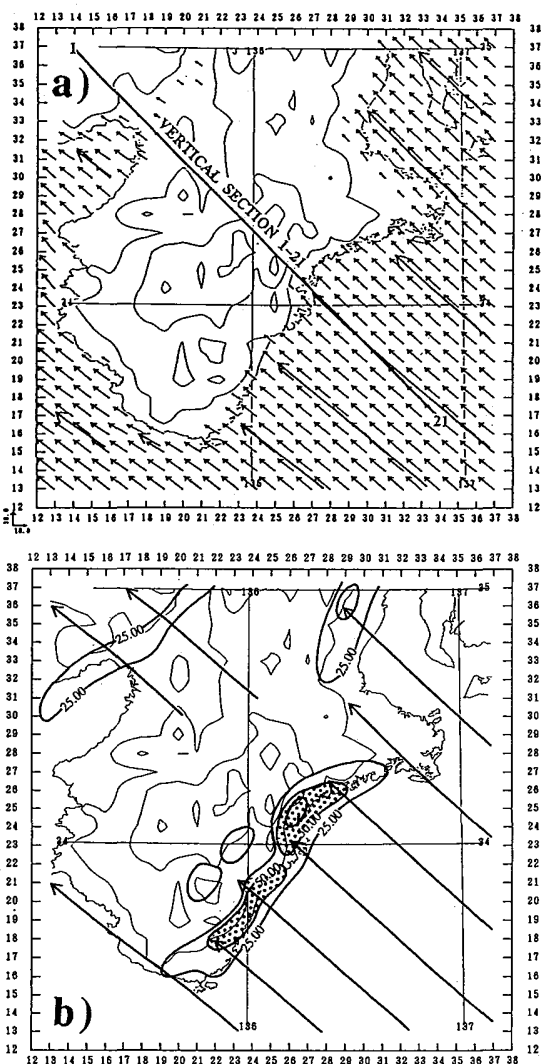

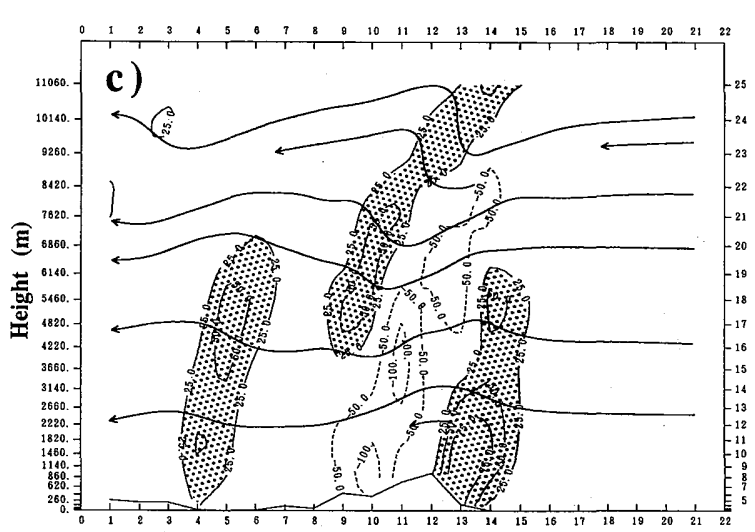

Fig. 31 (a) Same as Fig. 25a but by 30 June experiment. (b) Streamlines and updraft averaged in the layer from surface to $1460 \mathrm{~m}$ level. Contour interval is $25 \mathrm{~cm} / \mathrm{s}$. Vertical velocity is larger than $50 \mathrm{~cm} / \mathrm{s}$ in shaded areas. (c) Vertical cross-section of vertical velocity along 1-21 line in (a). Contour intervals are $25 \mathrm{~cm} / \mathrm{s}$ and $50 \mathrm{~cm} / \mathrm{s}$ in updraft and downdraft areas, respectively. Vertical velocity is larger than $25 \mathrm{~cm} / \mathrm{s}$ in shaded areas. 


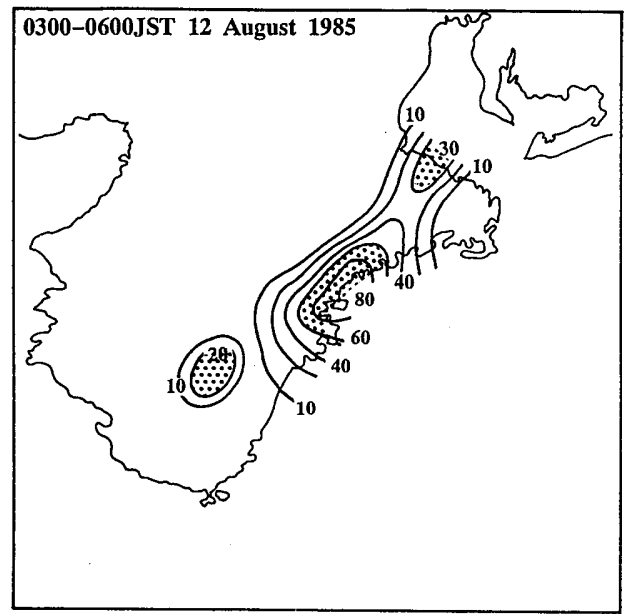

Fig. 32 Same as Fig. 23 but from 0300 to 0600 JST on August 12.

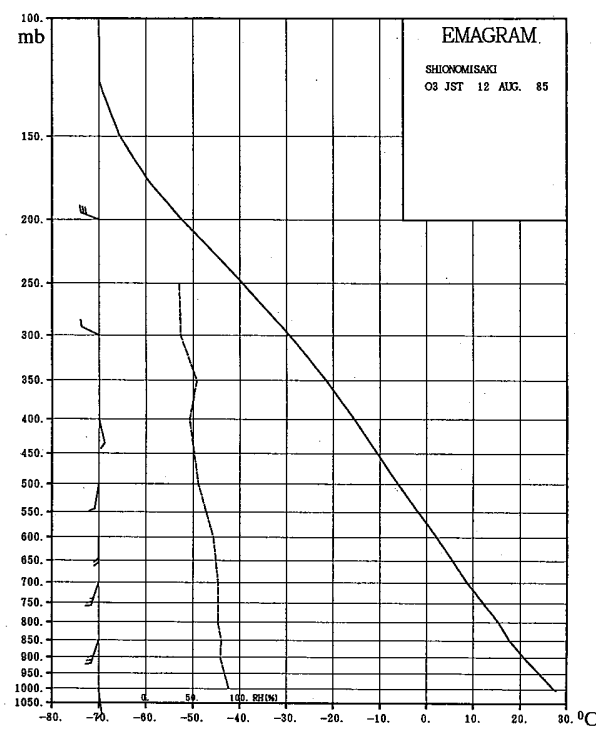

Fig. 33 Same as Fig. 24 but 0300 JST on August 12.
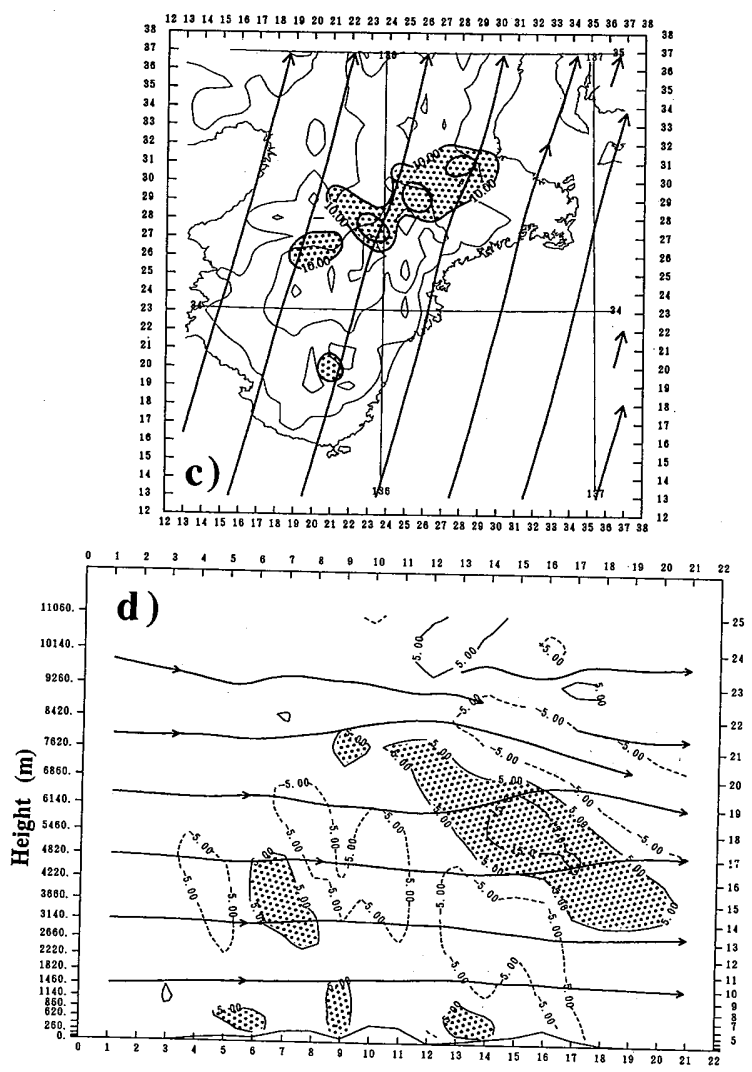

Fig. 34 Same as Fig. 28 but by August 12 experiment. 
from a traveling cloud system — can be combined.

The results of numerical experiment in the case in which heavy rains were observed (Section 4) show a good correlation between the distribution of rainfall and the distribution of computed updraft areas at lower levels. In the situation of easterly, southeasterly or southerly wind, two areas of computed low-level updraft are found around Owase and in the southern part of the Kii peninsula. The distribution of rainfall in the Kii peninsula could be roughly divided into two types - strong-wind type and weak-wind type. The first one is characterized by heavy-rain areas which are located deeper inland. The distribution of rainfall in this type has a good correlation with the distribution of high mountains, that is, larger rainfall amounts are observed in areas of greater altitudes. In the weak-wind type, heavy-rain areas are mainly located along the sea-shore around Owase and in the southern part of the peninsula.

The horizontal distribution of low-level updraft induced by a mountain is dependent on atmospheric conditions. In the case of weak wind, the computed low-level updraft area has the tendency to spread to the sea on the windward side of the mountain. In the case of strong wind, it extends to greater altitudes and is concentrated above the windward slope of the mountain. The difference in the horizontal distribution of rainfall in the Kii peninsula between situations of weak wind and typhoon strong wind might reflect the shift of the low-level updraft area from offshore to the windward slope of the mountain in the case of strong wind.

The relationship between the horizontal distribution of rainfall and the velocity of prevailing wind can be observed around the Orofure mountains in Hokkaido. According to the observation of rainfall by Kikuchi et al. (1988), the difference in the distribution of rainfall between so-called plain-centered pattern and seaside pattern results from different wind speed. Enhanced-rainfall areas are located deeper inland in the case of stronger wind.

In the case of southeasterly weak wind, computed low-level updraft is located at some distance from the mountain base. The curved shape of mountains along the southeastern seashore in the Kii peninsula has an influence on the airflow at low levels. The band-like convergence zone is found over the sea, and it results in a secondary updraft line. Clouds can be formed along this line. The band of precipitating clouds observed by Takeda and Takase (1980) might be associated with this line. The position of the cloud band in its early stage (Fig. 7 of Takeda and Takase) is coincident with the position of the computed updraft line in the case of southeasterly wind.

Numerical experiments show that two areas of updraft can be found at low levels above the mountain slope and over the sea in the case of weak and moderate winds. Traveling convective clouds are subject to the enhancement of rainfall induced by those updrafts. Radar observation (Takeda and Takase, 1980) suggested that the enhancement of rainfall occurred two times in convective clouds which landed around Owase. In their Fig. 9, precipitating clouds were intensified over the sea and after landing.

The vertically propagating mountain wave has updraft and downdraft at middle levels which are tilted upstream. Their inclination is dependent on wind velocity and thermal stability. Middle-level clouds might be influenced by these airflows. Downdrafts would dry out clouds, and in contrast, updrafts can enhance clouds. The comparison of computational results with the distribution of rainfall on April 4, May 25 and August 12 shows a good correlation between the position of computed middle-level updraft and the position of the heavy-rain area.

The distribution of hourly rainfall of these cases indicates that the rain area which was originated around Owase moved in the direction of wind at middle levels. When southerly to south-southwesterly wind is predominant at low levels and southwesterly wind at middle levels, computed low-level convergence can be found around Owase. Probably orographic convective clouds formed around Owase must have moved northeastward in such cases. An interesting observational fact in April 4 and May 25 cases is that the rainfall intensity of the moving rain area increased on the northeastern side of 
Owase, which is the lee side of mountains with regard to the wind direction at middle levels.

In addition to the weak-wind type and strong-wind type described above, the distribution of rainfall observed to the northeast of Owase in the cases of April 4, May 25 and August 12 can be considered as the third type of orographic enhancement of rainfall in the Kii peninsula. This type is often observed in the situation of south-southeasterly to south-southwesterly wind at low levels and southwesterly wind at middle levels. The topographic features of the Kii peninsula and this directional vertical wind shear can produce a strong influence on the modification of rainfall. The combination of the generation of orographic clouds on the windward side of a mountain and the enhancing of these clouds on its lee side will be an interesting problem.

In this study, we used a "dry model" and studied primary forcing by three-dimensional orography to the flow over Kii peninsula. However, if there is the condensation of water vapor, the atmospheric stability using the equivalent potential temperature decreases. From this point of view, the simulations conducted in sub-section 4.3 might overestimate the effective thermal stability.

There are some differences between the computed updrafts and observed rain. In our cases, observed rain at Shionomisaki is much less than that at Owase, while the updrafts in the southern part of the Kii peninsula are nearly comparable to those around Owase in the simulations. Omitting cloud microphysics as well as the simplification of initial and boundary conditions may cause the differences. In the case of June 30, the computed updraft was located on the windward side compared to the observation. Transportation of ice-phase precipitating particles by strong wind might explain this locational deviation. In the numerical experiment of orographic snowfall over Northern Japan, Saito et al. (1994a) has reported that snow was transported $20 \mathrm{~km}$ leeward by winds of 10 $\mathrm{m} / \mathrm{s}$. Further study on the orographic enhancement of rainfall in the Kii peninsula by using a "wet model" is under way (Saito et al., 1994b). The results will be reported at a later date.

\section{Summary}

In order to understand the influence of mountain airflow on the orographic enhancement of rainfall in the Kii peninsula, numerical experiments with a three-dimensional nonhydrostatic model were conducted and simulated low-level updraft patterns were compared with the real distributions of rainfall.

1) In the situation of easterly, southeasterly or southerly wind, computed low-level updraft areas are found around Owase and in the southern part of the Kii peninsula, where heavy rain is often observed.

2) The distribution of rainfall enhanced by orographic effect in the Kii peninsula can be roughly divided into two types: strong-wind type and weak-wind type. The shift of heavy-rain areas from the seashore region (weak-wind type) to the region located deeper inland (strong-wind type) can be explained by the displacement of low-level updraft areas in the windward side.

3) The curved shape of mountains along the southeastern seashore in the Kii peninsula influences airflow at low levels. In numerical experiments a band-like updraft area was formed over the sea in the situation of weak wind. The band of convective clouds is often observed along this area.

4) Middle-level updraft induced by vertically propagating mountain waves might enhance rainfall originated from middle-level clouds which pass over the mountain. In some cases, observed heavy-rain areas were located beneath simulated middle-level updraft areas.

\section{Acknowledgments}

The original manuscript of this paper was based on the master thesis of Lecong Thanh, who had stayed at Nagoya University as a visiting student. The work was achieved as a collaborating program between the Meteorological Research Institute and Nagoya University, which was partly supported by Scientific Research Fund from the Ministry of Education. The authors express their condolence on the 
death of the late Dr. Motohki Ikawa, who promoted this project initially.

The authors thank students of the Laboratory of Atmospheric Water Cycle of the Institute for Hydrospheric and Atmospheric Sciences of Nagoya University for their valuable help. They also thank Mr. Masahiro Hara of MRI for his help in the preparation of a draft of this paper. Thanks are extended to the two anonymous reviewers for their valuable comments and constructive criticism on the earlier versions of this paper. Numerical computation was performed using the Nagoya University's computer system FACOM VP-2600 and the MRI's computer system HITAC S-810 and S-3800.

\section{References}

Clark, T.L., 1977: A small-scale dynamic model using a terrain-following coordinate transform. J. Comp. Phys., 24, 186-215.

Deardorff, J.W., 1980: Stratocumulus-capped mixed layers derived from a threedimensional model. Boundary-Layer Meteorol., 18, 495-527.

Durran, D.R. and J.B. Klemp, 1982: The effect of moisture on trapped mountain lee waves. J. Atmos. Sci., 39, 2490-2506.

Ikawa, M. and K. Saito, 1991: Description of a non-hydrostatic model developed at the Forecast Research Department of the MRI. Tech. Rep. of the MRI, 28, 238pp.

Ikawa, M., H. Mizuno, T. Matsuo, M. Murakami, Y. Yamada and K. Saito, 1991: Numerical modeling of the convective snow cloud over the Sea of Japan. J. Meteor. Soc. Japan, 69, 641-667.

Kikuchi, K., N. Horie, T. Harimaya and T. Konno, 1988: Orographic rainfall events in the Orofure mountain range in Hokkaido, Japan. J. Meteor. Soc. Japan, 66, 125-139.

Klemp, J.B. and R. Wilhelmson, 1978: The simulation of three-dimensional convective storm dynamics. J. Atmos. Sci., 35, 10701096.

Kondo, J., 1975: Air-sea bulk transfer coefficients in diabatic conditions. BoundaryLayer Meteorol., 9, 91-112.

Orlanski, I., 1976: A simple boundary condition for unbounded hyperbolic flows. J. Comp. Physics, 21, 251-269.

Saito, K. and M. Ikawa, 1991a: A numerical study of the local downslope wind "Yamajikaze" in Japan. J. Meteor. Soc. Japan, 69, 31-56.

Saito, K. and M. Ikawa, 1991b: Numerical simulation of local winds by a threedimensional nonhydrostatic model. Technical Report submitted to the annual meeting of JMA for improvement of forecasting technique, MRI, 36-60 (in Japanese).

Saito, K., 1993: A numerical study of the local downslope wind "Yamaji-kaze" in Japan. Part 2: Non-linear aspect of the 3-D flow over a mountain range with a col. J. Meteor. Soc. Japan, 71, 247-271.

Saito, K., T. Matsuo, M. Murakami, H. Mizuno and M. Ikawa, 1994a: Numerical experiments of the orographic snowfall over the mountainous region of Northern Japan. BMRC Research Report, Bureau of Meteor. ology Research Centre, 46, 143-148.

Saito, K., S. Kanada, L. Thanh and T. Takeda, 1994b: Orographic effect of the Kii Peninsula on its rainfall distribution. Part 3. Proceeding of annual conference of the Meteor. Soc. Japan, 66, 203 (in Japanese).

Sakakibara, H. and T. Takeda, 1973: Modification of typhoon 7002 rainfall by orographic effect. J. Meteor. Soc. Japan, 51, 155-167.

Smith, R. B., 1980: Linear theory of stratified hydrostatic flow past an isolated mountain. Tellus, 32, 348-364.

Smith, R. B., 1989a: Mountain-induced stagnation points in hydrostatic flow. Tellus, 41A, 270-274.

Smith, R. B., 1989b: Hydrostatic airflow over mountain. Advances in geophysics, 31, 1-41.

Smolarkiewicz, P. K., R. M. Rasmussen and T. L. Clark, 1988: On the dynamics of Hawaiian cloud bands: Island forcing. J. Atmos. Sci., 45, 1872-1905.

Smolarkiewicz, P. K. and R. Rotunno, 1989: Low Froude number past three-dimensional obstacles. Part 1: Baroclinically generated lee vortices. J. Atmos. Sci., 46, 1154-1164.

Smolarkiewicz, P. K. and R. Rotunno, 1990: Low 
Froude number flow past three-dimensional obstacles. Part 2 : Upwind flow reversal zone. J. Atmos. Sci., 47, 1498-1511. Sommeria G, 1976: Three-dimensional simulation of turbulent process in an undisturbed trade wind boundary layer. J. Atmos. Sci., 33, 216-241.

Takeda, T., N. Moriyama and Y. Iwasaka, 1976: A case study of heavy rain in Owase area. J. Meteor. Soc. Japan, 54, 32-41.
Takeda, T. and K. Takase, 1980: Radar observation of rainfall system modified by orographic effect. J. Meteor. Soc. Japan, 58, 500-516.

Tripoli, G. J. and W. R. Cotton, 1989: Numerical study of an observed orogenic mesoscale convective system. Part 1: Simulated genesis and comparison with observation. Mon. Wea. Rev., 117, 273-304.

\title{
紀伊半島の降雨量分布に対する地形の効果について
}

\author{
斉藤和雄・ Lecong Thanh* · 武田喬男**
}

紀伊半島, 尾鷲付近での降雨の集中に対する地形効果をみるため，3 次元山岳地形を越える流れの場を非静 水压ドライモデルを用いて調べ，観測された降雨量分布との比較を行った。

北東一南西方向に長軸を持つ楕円で単純化した地形に対する数值実験では，南東の一般風が弱い場合，山岳


次的な上昇流で, 山岳前面最下層の逆風を伴っていた。それぞれのピークは一般風が小さいほど風上側に生ず るが，一般風が強く（あるいは安定度が小さく）ブロッキングが生じない場合は，海上の 2 次的な上昇流は見 られない。紀伊半島地形の特徵的な湾曲は, 南東風時のブロッキングの効果を高める働きを持つ。

1985年の紀伊半島での降水事例を解析し，尾鷲では潮岬に比べ雨量が多い事と大雨は東南東一南の下層風向 時に生じている事を確かめた。紀伊半島の現実地形を用いた数値実験では，東一南のいずれの風向時にも尾鷲


の極大地点と良い一致が見られた。ブロッキングにともなう海上の 2 次的な上昇流は南西～西の風向時には生 じなかった。

大雨時に観測された一般場を用いた数值実験でも同様な傾向が見られ，シミュレーションで得られた下層の 上昇流域は観測された降水分布に概ね良く対応していた。また，いくつかのケースでは，尾鷲の北東で観測さ れた地上の降水域に対応する場所に山岳波による風下側中層の上昇流域がシミュレートされた。

実験結果は, 実際の降雨分布と一般風の大きさの関係 ——弱風時の海岸域と強風時の内陸域 ——に対応 している。また，弱風時にしばしば見られる紀伊半島風上側海上での対流性降雨バンドの発達に，紀伊半島の 地形のブロッキングによる下層の水平収束が影響している事を示唆している。

* 名古屋大学大気水圈科学研究所 (現所属: ベトナム水文気象局予報部)

**. 名古屋大学大気水圈科学研究所 